\title{
Comparative study of the nematode communities on the southeastern Weddell Sea shelf and slope (Antarctica)
}

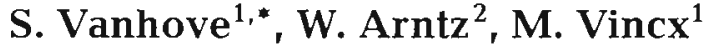 \\ ${ }^{1}$ University of Gent, Department of Zoology, Marine Biology Section, K.L. Ledeganckstraat 35, B-9000 Gent, Belgium \\ ${ }^{2}$ Alfred Wegener Institute for Polar and Marine Research, Columbusstrasse, D-27568 Bremerhaven, Germany
}

\begin{abstract}
Nothing is known about the structure of free-living marine nematode communities in the high Antarctic. Our attempt at surveying this numerically most abundant meiobenthic taxon along the continental shelf and slope $(200$ to $2000 \mathrm{~m}$ ) furnished information on generic, trophic and age composition in 2 regions in the Weddell Sea (Kapp Norvegia, 6 stations, $71-72^{\circ} \mathrm{S}, 12-13^{\circ} \mathrm{W}$; Halley Bay, 11 stations, $74-75^{\circ} \mathrm{S}, 25-29^{\circ} \mathrm{W}$ ). A total of 7300 nematode identifications to generic level were analyzed by means of a variety of statistical techniques. The spatial structure indicated the existence of 4 major nematode genus associations colonizing the upper slope, downslope, Halley shelf and a mixed habitat consisting of shelf break and Kapp Norvegia shelf. Dominated by genera like Sabatieria, Molgolaimus, Microlaimus, Monhystera, Daptonema, Leptolaimus, Acantholaimus and Dichromadora, these habitats often contained distinct associations of less abundant genera. The trophically diverse communities exhibited an equal sharing of epistrate, nonselective and selective deposit feeders, with a slight dominance of the first feeding category. Each feeding guild was considered in light of the correlations with microbial food and fresh versus decomposing organic matter, leading to the conclusion that the applied classification does not adequately explain the trophic status of the deep-water communities. Globalscale comparisons with literature data indicated the broad geographical distribution of predominant nematode taxa and a lack of Antarctic endemism. Only a weak separation of the entire nematode communities on a geographical basis was suggested by multivariate techniques. Although ocean-wide comparison was hampered by limited comparable literature data, diversity indices scored high and surpassed the Arctic bathyal assemblage. The major agents behind the observed patterns involved sediment grain size and food content, operating over different scales. Depth per se had no major effect. Underlying mechanisms included water-column productivity, hydrodynamics, iceberg activity and macrofaunal presence.
\end{abstract}

KEY WORDS: Continental margin - Antarctica · Free-living marine nematodes - Environment

\section{INTRODUCTION}

Meiobenthic assays in the soft-bottom marine sediments of the Weddell Sea indicate that this fauna shares many characteristics with counterparts on other deeper seafloors (Herman \& Dahms 1992, Vanhove et al. 1995). However, these publications treated only gross taxonomic groups. The current study focusses on the generic level of the nematodes, the numerically

•E-mail: sandra.vanhove@rug.ac.be most abundant phylum within the meiofauna. It provides a geographically extensive nematode database from one of the largest shelf areas around the Antarctic continent. The purpose is 4 -fold.

(1) Despite many reports on nematode assemblages in deep water (Tietjen 1971, 1976, 1984, 1989, Vivier 1978a,b, Dinet \& Vivier 1979, Thistle \& Sherman 1985, Rutgers van der Loeff \& Lavaleye 1986, de Bovée 1987. Jensen 1988, 1992, Renaud-Mornant \& Gourbault 1990, Vanreusel et al. 1992, 1997), only 4 studies addressed full transects crossing the shelf and slope (Soetaert et al. 1991, Soetaert \& Heip 1995, Vanaverbeke et al. 
1997 a,b). Nevertheless, this transition zone between coast and deep sea is often denoted as being the most heterogeneous (Wilson \& Hessler 1987). More investigations are essential for understanding the complexity of deep-water communities. By comparing the nematode community structure in the Weddell Sea with other ocean-margin assemblages on the globe, this study will also improve our knowledge on the structure of the Antarctic marine ecosystem, which is likely the most sensitive to global environmental change.

(2) Studies on the macrobenthic level largely separated the Weddell Sea into an eastern shelf community, typified by sessile, suspension-feeding bryozoans and hexactinellids, and a southern shelf community, described as being an association of holothurians, asteroids, polychaetes, echinoids and decapod shrimps (VoB 1988, Hain 1990, Gutt 1991, Galéron et al. 1992. Gerdes et al. 1992, Hempel 1992). The current investigation will check whether the nematode fauna in the southeastern Weddell Sea has affinities with these 2 macrobenthic communities.

(3) Meiofauna is organized into aggregations at different scales ( $\mathrm{Li}$ et al. 1997). The spatial variability is related to physical (Montagna 1991), chemical (Wetzel et al. 1995) and biological factors (Blanchard 1990, Hall et al. 1994). This survey will describe how environmental agents interact and control meiofauna distribution at various scales (station, subregion, region).

(4) Today's challenge to many researchers of the marine environment is to find answers to the questions dealing with diversity clines along depth gradients (Gray et al. 1997) or latitudinal gradients (Arntz \& Gallardo 1994). The general opinion is that, e.g., the deep sea and Antarctica contain highly diverse communities, though this view is far from straightforward and certainly requires confirmation from further sampling. Very few biodiversity measures deal with free-living nematode communities in the deep sea, and no information at all is available from the Antarctic. This paper will present the first measures of genus diversity of Antarctic nematode communities to compare with other deep-water assemblages.

\section{MATERIALS AND METHODS}

Study area, meiofauna and nematode treatment. The samples were taken in the Weddell Sea at Kapp Norvegia $\left(71-72^{\circ} \mathrm{S}, 12-13^{\circ} \mathrm{W}\right.$, station numbers starting with $\mathrm{K})$ and Halley Bay $\left(74-75^{\circ} \mathrm{S}, 25-29^{\circ} \mathrm{W}\right.$, station numbers starting with $\mathrm{H}$ ) at depths varying between 211 and $2080 \mathrm{~m}$, that is, on the continental shelf and slope sensu Grobe (1986) (Fig. 1). Along the transects, variation in grain size was sometimes high, with the medium sand fraction (0.5 to $0.25 \mathrm{~mm}$ ) ranging between 1 and $25 \%$. A significant presence of pellite (sometimes over $90 \%$ ) and gravel (sometimes over $40 \%$ ) indicated differing sedimentation and hydrodynamic processes. All sediments were very poorly to extremely poorly sorted. Information on the sampling of the environmental variables as listed in Table 1 was provided elsewhere (Arntz et al. 1990, Vanhove et al. 1995).

Meiofauna sampling was performed by multibox corer (MG) and multicorer (MUC); each meiofauna replicate originated from a $10 \mathrm{~cm}^{2}$ subsample (minimum sediment depth of $10 \mathrm{~cm}$ ) of a separate box (MG) or core (MUC) from the same cast. The procedure for organism processing followed Higgins \& Thiel (1988); a $38 \mu \mathrm{m}$ sieve was used to extract the meiofaunal size class. The nematode numbers and their relative contribution to total meiofauna counts were discussed in Vanhove et al. 1995 and are summarized in Table 1. A random set of 200 nematodes from 2 to 3 cores were mounted on glycerin slides (Seinhorst 1959). Identification to genus level was done using the pictorial keys of Platt \& Warwick (1988) and relevant taxonomic literature (Gourbault \& Boucher 1981, Platt 1985, Soetaert $\&$ Vincx 1988, Bussau 1993). The nematodes were classified according to Lorenzen (1994). The 4 feeding groups suggested by Wieser (1953), distinguishing selective (1A) and nonselective (1B) deposit feeders, epistratum feeders (2A) and predators/omnivores (2B), linked to buccal morphology, were used to investigate the trophic structure of the assemblages.

Data analysis. Replicability and small-scale patchiness: The variance to mean ratio of the nematode genus numbers per station was used to detect departure from randomness. The $\chi^{2}$-test of sampling accuracy (Heip et al. 1988) indicated that differences between replicates at each station were minimal (e.g. with exception of $K 4$, the median $\chi^{2}$ per station varied between 0.1 and 7.4 with 1 or 2 degrees of freedom, giving a nonaggregated dispersion at the $2.5 \%$ significance level). K4C appeared an erratic replicate, and was therefore eliminated before averaging the data for further statistical analyses. A test for the small-scale distribution of trophic and age composition within a station was done on the pooled genera per replicate.

Community structure: To define communities spatially, the mean percentages per station at the genus level of organization were used as input for the TwoWay Indicator Species Analysis--TWINSPAN (Hill 1979). First, as rare genera can be informative on the state of the community, the nonreduced, nontransformed percentage data matrix (158 genera) with cutlevels $0.00,0.29,0.59,1.41$ and 8.20 was used for total analysis (the intermediate cutlevels were chosen so that an equivalent number of observations were present at each cutlevel, the highest cutlevel was chosen 
(w) 47dap

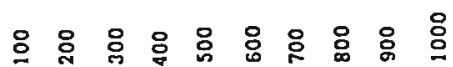

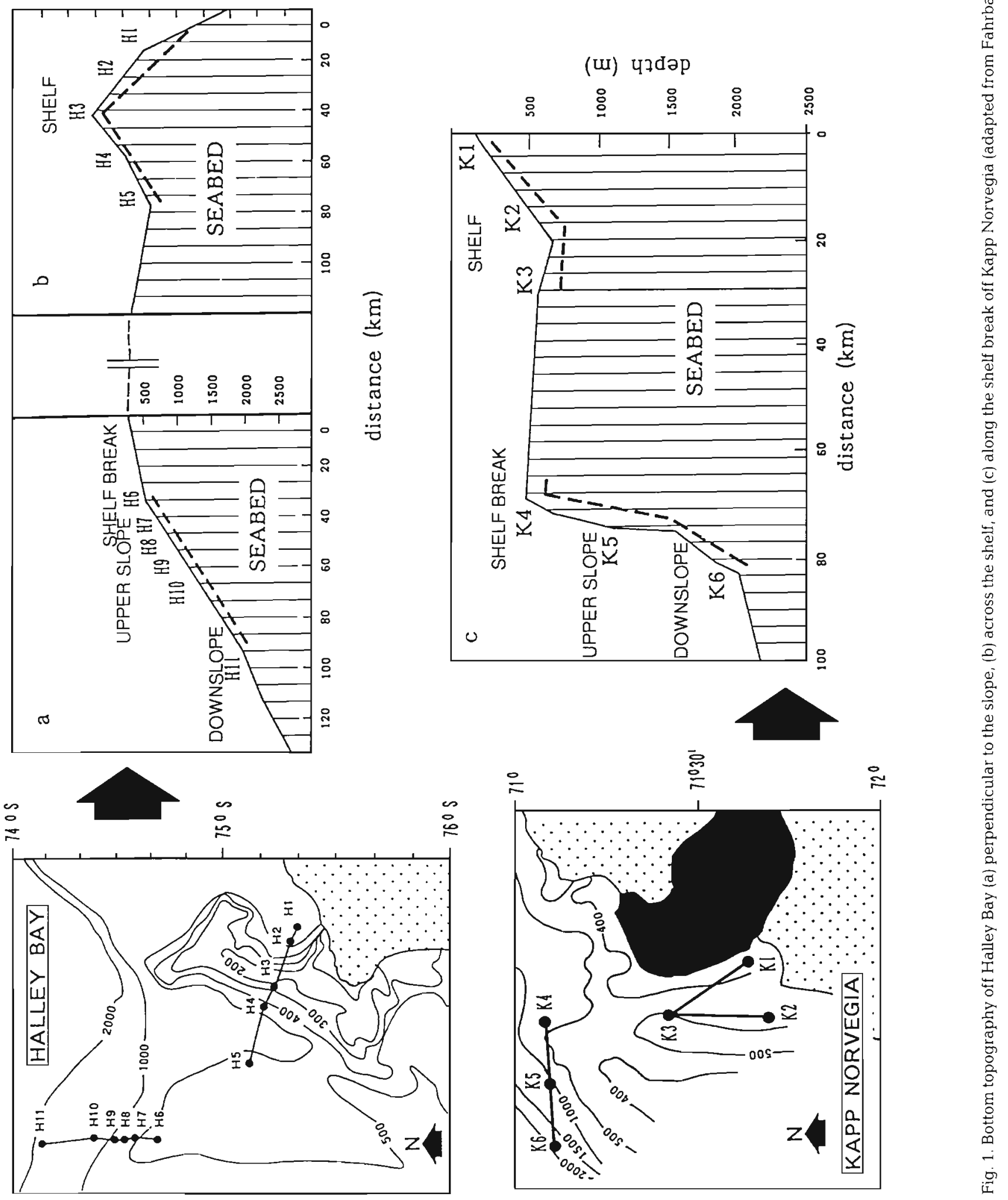




\begin{tabular}{|c|c|c|c|c|}
\hline$\vec{\Xi}$ & $\stackrel{己}{\Sigma}^{2}$ & 舫: & 吕 & : \\
\hline$\stackrel{\ominus}{I}$ & $\sum_{\Sigma} \sim$ & 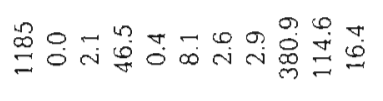 & 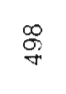 & $\begin{array}{l}\overrightarrow{0} \\
\bar{\sigma}\end{array}$ \\
\hline 0 & 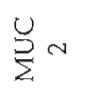 & 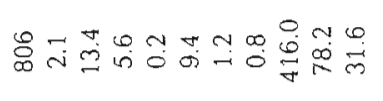 & 审 & क人 \\
\hline$\stackrel{\infty}{I}$ & $\stackrel{\sum}{\Sigma}^{U}$ & 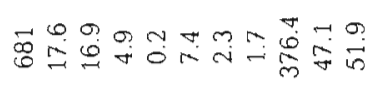 & $\stackrel{\widetilde{F}}{\forall}$ & 焉学兽 \\
\hline 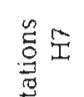 & $\bigcup_{2} \infty$ & 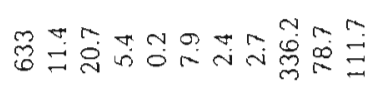 & $\underset{\sigma}{\stackrel{\vec{a}}{\sigma}}$ & $\vec{\infty}$ \\
\hline 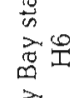 & $\breve{Z}_{\Sigma} N$ & 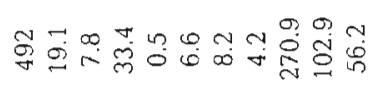 & $\underset{\sigma}{\mathscr{\sigma}}$ & $\stackrel{\infty}{\infty} \stackrel{\sim}{\vec{\nu}} \stackrel{\infty}{\sim}$ \\
\hline 总里 & $\breve{Z}_{2} N$ & 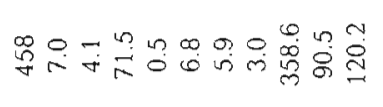 & 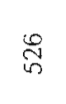 & 裉 \\
\hline 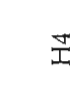 & $\mathrm{y}_{\Sigma}$ & 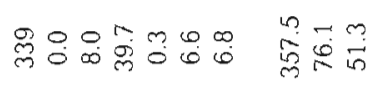 & $\underset{W}{\stackrel{\infty}{\sim}}$ & $\vec{g} \vec{S} \vec{g}$ \\
\hline$\stackrel{m}{I}$ & $\stackrel{U}{\Sigma}_{N}$ & 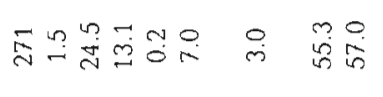 & & 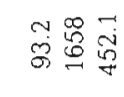 \\
\hline$\tilde{I}$ & $\stackrel{巳}{\Sigma} \sim$ & 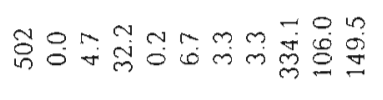 & $\stackrel{\infty}{\vec{\sigma}}$ & 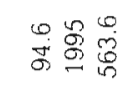 \\
\hline $\bar{I}$ & $\sum_{\Sigma} N$ & 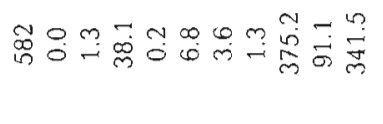 & $\stackrel{\infty}{8}$ & $\begin{array}{l}0 \\
\dot{S} \\
\dot{\sigma}\end{array}$ \\
\hline $\mathscr{Y}$ & $\stackrel{U}{\Sigma}^{U} m$ & 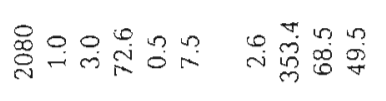 & \% & 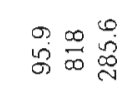 \\
\hline $\mathfrak{g}_{g}^{\mathscr{g}}: \mathfrak{w}$ & 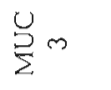 & $\begin{array}{l}g \\
g\end{array}$ & $\stackrel{\sigma}{\sigma}$ & 苋员总 \\
\hline 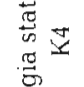 & $\stackrel{U}{\Sigma} \sigma$ & 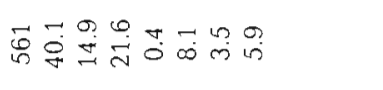 & & 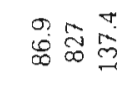 \\
\hline$\sum_{\substack{0 \\
2}}^{\infty} \tilde{x}$ & $\sum_{\Sigma}^{U}$ & 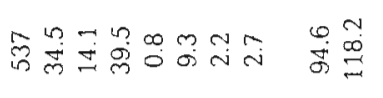 & & 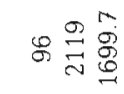 \\
\hline 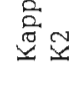 & $y_{m}$ & 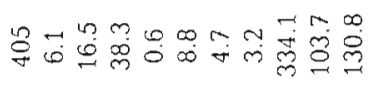 & 号 & 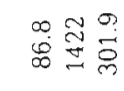 \\
\hline $\bar{x}$ & $\frac{U}{2} m$ & $\underset{\sim}{\vec{v}} \quad \stackrel{N}{\infty}$ & & 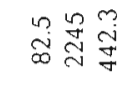 \\
\hline 总 & & 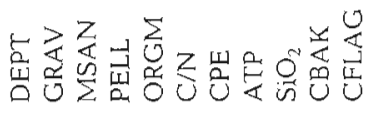 & $\frac{\Gamma}{\varphi}$ & \\
\hline & 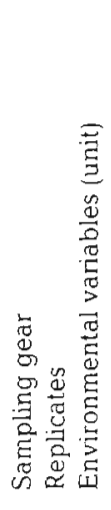 & 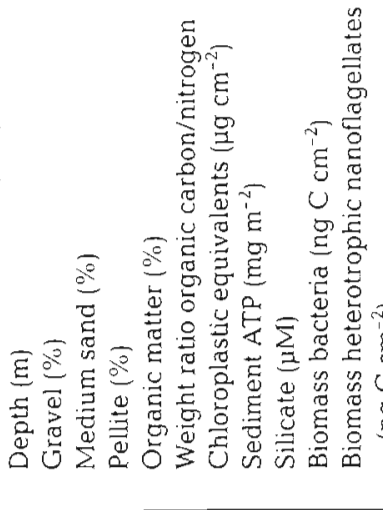 & 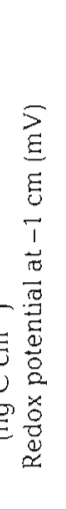 & 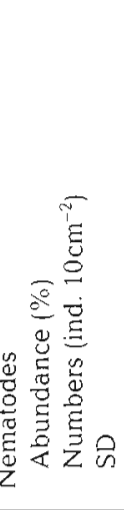 \\
\hline
\end{tabular}

so that the highest scores were reduced in weight compared to the rest of the dataset).

Second, 2 reduced datasets for assessing the impact of the dominant genera were applied. To this end, the median $(0.11 \%)$ and mean $(0.61 \%)$ genus percentage of the entire data matrix were defined. Hence, genera with a relative abundance in the full station set (percent of total) of less than $0.61 \%$ (reduction of $47 \%$ ) and $0.11 \%$ (reduction of $78 \%$ ) were subjected to classification.

To assess the consistency of these TWINSPAN results, the clustering statistic group-average sorting (GAS) with Bray-Curtis similarities (Bray \& Curtis 1957) on the same datasets and an exploratory Correspondence Analysis (CAoption from the program package CANOCO, Ter Braak 1988) on the arcsin-transformed data matrix were done.

A Kruskal-Wallis $H$-test was performed to look for significant differences in nematode composition between Kapp Norvegia and Halley Bay.

Genus diversity: The diversity measures employed were calculated on all nematodes identified per station, i.e. in subsamples of about 300 to 600 specimens. They included $N_{0}$ (number of genera) and the Shannon diversity index of species-richness $H^{\prime}=-\sum\left(p_{i} \log _{2} p_{i}\right)$ (Pielou 1975). Hurlbert's modification of Sanders' rarefaction curves (Hurlbert 1971; BioDiversity-ecological analysis program, copyright Natural History Museum, London, and Scotish Association for Marine Science, Oban) were used to determine $E(G 100)$, the expected number of genera present in a population of 100 individuals. This diversity measurement (based on a lognormal distribution of the genera) is independent of sample size (i.e. the number of genera identified), allowing comparison of the different stations and regions in the Weddell Sea (alpha and beta diversity sensu Whittaker 1960) and of geographical areas on a global scale (gamma diversity sensu Cody 1986). Trophic diversity was calculated to describe the diversity in feeding types as $T=\sum \vartheta^{2}$, with $\vartheta$ the proportion of each feeding type in the assemblage (Heip et al, 1984). Trophic diversity is highest when all feeding types are equally present (e.g. $T=0.25$ ) and lowest when only one trophic type is present (e.g. $T=1$ ).

A Kruskal-Wallis $H$-test and subsequent Mann-Whitney $U$-tests (Siegel 1956) were performed to look for significant differences in diversity between Kapp Norvegia and Halley Bay and between the TWINSPAN-clusters. 
Environmental effect: The relationship between community structure and environmental variables was examined using the ordinatory Canonical Correspondence Analysis (CCA, also from the CANOCO package). The environmental variables included water depth; porosity; sediment texture: percentage of gravel, medium sand, very coarse sand, sand, silt, clay; potential food: organic nitrogen, organic carbon, chlorophyll a, phaeopigments, adenosine triphosphate (ATP), respiratory electron transport system (ETS), numbers and biomass of bacteria, numbers and biomass of heterotrophic nanoflagellates in different size classes; interstitial nutrients: $\mathrm{SiO}_{2}$, $\mathrm{PO}_{4}, \mathrm{NO}_{2}, \mathrm{NO}_{3} ;$ redox potential (Eh) at each sediment slice of $1 \mathrm{~cm}$ to a depth of $5 \mathrm{~cm}$. As many variables proved to be redundant only 10 were retained: depth, percentage gravel, medium sand, pellite (silt + clay), organic matter (carbon + nitrogen), chloroplastic equivalents (chlorophyll a + phaeopigments), biomass of bacteria and flagellates, concentration of silicate, and Eh. The method to choose the best variables was to run CANOCO with the subsequent addition of environmental variables (without forward selection) and test the additional effect of the variable with a Monte Carlo permutation test (Ter Braak 1990).

The missing values were calculated by interpolating from data of neighbourhood stations (e.g. the missing value of chloroplastic equivalents (CPE) at Stn $\mathrm{H} 3$ was calculated as the mean of data from $\mathrm{H} 2$ and $\mathrm{H} 4$; the value at Stn K6 was an average of all other stations off Kapp Norvegia). As the environmental variables for K1 were not available, this station could not be used in the CCA. The approximate position was estimated from several CA outputs.

Additionally Spearman rank correlations were computed between the biotic percentage data and the reduced set of environmental variables (augmented with ATP and $\mathrm{C} / \mathrm{N}$ ). Only the significant relations below the $5 \%$ level were retained in the output.

Scales of nematode distribution: The spatial variability in the nematode populations was tested using variance to mean ratios (i.e. index of dispersion) at different scales (e.g. station, subregion, region). Multiplied by the degrees of freedom (= number of samples -1 ) a good estimate of the pooled $\chi^{2}$-statistic is given. A probability of $<2.5 \%$ indicates significant aggregation (Lambshead \& Hodda 1994). A high proportion of the genera proved to exhibit very low abundances, often with many zero values. In a first series the zero-mean and zero-variance for absent genera in a set of stations were eliminated; in a second set the nematodes with abundances lower than $0.11 \%$ throughout a set of stations were discarded. This data reduction was needed as rare genera drop below the resolving power of the test (Type II error, the power of the test becomes so low that nonrandom distribution cannot be distinguished from random, Lambshead \& Hodda 1994).

\section{RESULTS}

\section{Description of the populations}

About 7300 specimens were identified; of these $97 \%$ belonged to 158 genera. The remaining $3 \%$ could not be classified to genus level because of small size or bad mounting. Taxonomically doubtful specimens were pooled with related genera. Examples were Desmoscolex (Pareudesmoscolex and Desmoscolex), Greeffiella (Greeffiella and Prototricoma), Paramonhystera (Paramonhystera and Promonhystera), Monhystera (all monhysterids except for Diplolaimella), Gammarinema (Gammarinema, Geomonhystera, Thalassomonhystera), Araeolaimus (Araeolaimus and Pararaeolaimus) and Desmodora (Desmodora and Pseudochromadora campbelli).

Among the 40 families (Table 2), Chromadoridae were most dominant (15\%). They were followed by Comesomatidae $(12 \%)$, Desmodoridae $(11 \%)$ and $\mathrm{Mi}$ crolaimidae $(10 \%)$. Of the remaining families 14 were represented by $1 \%$ or more of the nematode community, whereas more than half of the families had relative abundances lower than $1 \%$. Xyalidae, Chromadoridae and Linhomoeidae were most diversified in terms of genus numbers, with respectively 16, 14 and 12 genera. On the level of genera, Sabatieria, with a relative (low) dominance of $8 \%$ ranked first, whereas Molgolaimus, Microlaimus, Monhystera and Dichromadora had abundances of more than $5 \%$ of the entire nematode populations (e.g. respectively $8,7,7$ and $6 \%$ in Table 3). Co-dominant genera were Daptonema (4\%), Leptolaimus (4\%), Acantholaimus $(3 \%)$ and Cervonema $(3 \%)$. Overall, $75 \%$ of the genera were present with abundances lower than $1 \%$.

Classification of the genera of the entire nematode population in the Weddell Sea into feeding guilds (Table 3 ) suggested a predominance of epistratum (2A: $34 \%, 44$ genera), selective deposit (1A: 30\%, 54 genera) and nonselective deposit feeders (1B: $28 \%, 34$ genera). The predators/omnivores were much less abundant (2B: 5\%, 26 genera) (the remaining 3\% was not identified). Differences among stations were considerable, revealing extreme ranges of feeding types: 18 to $49 \%(1 \mathrm{~A}), 22$ to $40 \%(1 \mathrm{~B}), 24$ to $55 \%(2 \mathrm{~A})$ and 2 to $13 \%(2 \mathrm{~B})$ (Table 4 ).

\section{Regional communities: Halley Bay versus Kapp Norvegia}

The dispersion patterns (given by the $\chi^{2}$-statistic, Table 5) indicated a high aggregation at the regional scale $(34 \%$ of the total nematode population and $61 \%$ of the common genera were aggregated at 1 of the 
Table 2. Overall relative abundance of the nematode families collected in the Weddell Sea listed in descending order of importance, and with indication of the number of genera found

\begin{tabular}{|c|c|c|}
\hline Family & $\%$ of total & No. of genera \\
\hline Chromadoridae & 14.90 & $13+1$ undefined \\
\hline Comesomatidae & 11.98 & $7+1$ undefined \\
\hline Desmodoridae & 10.66 & 4 \\
\hline Microlaimidae & 10.16 & 6 \\
\hline Monhysteridae & 8.91 & $4+1$ undefined \\
\hline Xyalidae & 8.89 & $15+1$ undefined \\
\hline Leptolaimidae & 5.75 & 6 \\
\hline Diplopeltidae & 3.78 & 6 \\
\hline Oxystominidae & 3.15 & 7 \\
\hline Cyatholaimidae & 3.01 & 10 \\
\hline Aegialoalaimidae & 2.58 & 3 \\
\hline Desmoscolecidae & 2.16 & $5+1$ undefined \\
\hline Selachinematidae & 1.97 & 5 \\
\hline Linhomoeidae & 1.69 & $11+1$ undefined \\
\hline Monoposthiidae & 1.58 & 1 \\
\hline Anticomidae & 1.48 & 3 \\
\hline Ceramonematidae & 1.46 & 3 \\
\hline Meyliidae & 1.16 & 3 \\
\hline Ironidae & 0.82 & 1 \\
\hline Trefusidae & 0.79 & 3 \\
\hline Pandolaimidae & 0.64 & 1 \\
\hline Thoracostomopsidae & 0.44 & $5+1$ undefined \\
\hline Oncholaimidae & 0.43 & 2 \\
\hline Phanodermatidae & 0.35 & 4 \\
\hline Anoplostomatidae & 0.20 & 2 \\
\hline Epsilonematidae & 0.16 & 1 \\
\hline Sphaerolaimidae & 0.11 & 3 \\
\hline Coninckiidae & 0.11 & 1 \\
\hline Neotonchidae & 0.10 & 1 \\
\hline Axonolaimidae & 0.10 & 3 \\
\hline Rhabdodemanidae & 0.10 & 1 \\
\hline Draconematidae & 0.09 & 3 \\
\hline Enchelidiidae & 0.07 & 6 \\
\hline Haliplectidae & 0.04 & 1 \\
\hline Leptosomatidae & 0.04 & 2 \\
\hline Simpliconematidae & 0.04 & 1 \\
\hline Tubolaimoididae & 0.03 & 2 \\
\hline Siphonolaimidae & 0.03 & 1 \\
\hline Ethmolaimidae & 0.01 & 1 \\
\hline Tarvaiidae & 0.01 & 1 \\
\hline Total & 100.00 & $158+7$ undefined \\
\hline
\end{tabular}

2 regions). The within-group variation was higher in Halley Bay (49 to $69 \%$ ) compared to Kapp Norvegia (37 to $56 \%$ ).

Fig. 2 demonstrates that the 2 regions had, among the 5 most dominant genera (with a total of $40 \%$ of the entire nematode population), Sabatieria, Microlaimus, Monhystera and Dichromadora in common. The occurrence of Daptonema of Kapp Norvegia (with an average of 31 ind $10 \mathrm{~cm}^{-2}$, the 11 th most abundant) was, however, low compared to Halley Bay (with an average of 120 ind. $10 \mathrm{~cm}^{-2}$, the $3 r d$ most abundant), and the opposite was true for Molgolaimus (HB: 8th with
74 ind. $10 \mathrm{~cm}^{-2}$ i KN: 2nd with 143 ind. $10 \mathrm{~cm}^{-2}$ ). The genera Prochromadorella, Halichoanolaimus, Paranticoma and Calomicrolaimus in the Halley Bay assemblage were substituted by populations of Nudora, Southerniella, Camacolaimus, Gammarinema and Actinonema at Kapp Norvegia. TWINSPAN indicator families (classification outputs not depicted) for Kapp Norvegia were Monoposthiidae, Diplopeltidae, Ceramonematidae, Pandolaimidae and Sphaerolaimidae; and for Halley Bay, Selachinematidae, Anticomidae and Linhomoeidae. Deposit and epistratum feeders dominated at both sites, being roughly equally represented (about 30\% each). Except for the number of genera per 200 ind. $\left(\mathrm{N}_{0}\right)$, indices of structural and trophic diversity were identical (Kruskal-Wallis, $\mathrm{p}=0.03$ and $\mathrm{p}>0.05$ respectively)

\section{Subregional communities and distribution variability}

The TWINSPAN on the nonreduced genus dataset (Fig. 3A) divided the total nematode community into 4 major groups (in the following discussion termed subregions): the upper slope stations H7, 8,9 off Halley Bay (plus the midslope station K5 off Kapp Norvegia); the downslope stations K6, H11; the stations on the Halley shelf $\mathrm{H} 1,2,3,4,5$; and a heterogeneous group consisting of a mixture (MIX) of the shelf break stations $\mathrm{K} 4, \mathrm{H} 6$ at both transects (plus the midslope station H10) and Kapp Norvegia shelf stations K1, 2, 3 . The results were consistent between TWINSPAN and GAS for the full and reduced datasets, within a wide range of chosen cutlevels for TWINSPAN analysis, and for genus and family level of organization (not shown). Changes occurred in the positions of $\mathrm{K} 1, \mathrm{~K} 5$ and $\mathrm{H} 10$; these stations are not used for the characterisation of the nematode communities in the subregions (next paragraph). The CCA-ordination diagram (Fig. 3B) closely matched the TWINSPAN classification; only the shelf break cluster could not easily be identified. Centered genera (53\% of the total number) were indicated with an asterisk in Table 3 , and belonged to all feeding types. Other axis combinations (e.g. Axis 1/3, Axis $2 / 3$, etc.) gave more or less the same results.

Although Monhystera and Dichromadora were amongst the most dominant genera along the transects (Fig. 4), some clear community changes became manifest in the various subregions. The shallow-water nematodes, of which Monhystera, Microlaimus, Sabatieria, Dichromadora and Leptolaimus were the most prominent representatives, varied in their dominance on both shelves (Fig. 4A,B). Additonal TWINSPAN preferentials for the Halley shelf were Daptonema, Leptolaimus, Prochromadorella, Cervonema, Halichoanolaimus, Paracanthonchus, Calomi- 
Table 3. Overall relative abundance of the nematode genera collected in the Weddell Sea and sorted by feeding type; $3.4 \%$ of the total set was not identified. Genera in the center of the CCA species plot (Fig. 3B) are indicated with an asterisk

\begin{tabular}{|c|c|c|c|c|c|c|c|c|c|c|}
\hline \multicolumn{3}{|c|}{$\begin{array}{c}\text { Selective deposit } \\
\text { feeders } \\
\text { (\% total population) }\end{array}$} & \multicolumn{3}{|c|}{$\begin{array}{l}\text { Nonselective deposit } \\
\text { feeders } \\
\text { (\% total population) }\end{array}$} & \multicolumn{3}{|c|}{$\begin{array}{c}\text { Epistratum } \\
\text { feeders } \\
\text { (\% total population) }\end{array}$} & \multicolumn{2}{|c|}{$\begin{array}{l}\text { Predators/omnivores } \\
\text { (\% total population) }\end{array}$} \\
\hline Molgolaimus & $\cdot$ & 7.84 & Sabatieria & $\cdot$ & 8.44 & Microlaimus & & 7.39 & Halichoanolaimus & 1.22 \\
\hline Leptolaimus & $\cdot$ & 4.16 & Monhystera & $\cdot$ & 6.63 & Dichromadora & • & 6.07 & Syringolaimus & 0.79 \\
\hline Cervonema & $\cdot$ & 2.71 & Daptonema & $\cdot$ & 4.43 & Acantholaimus & 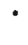 & 3.34 & Gammanema & 0.63 \\
\hline Aegialoalaimus & $\cdot$ & 2.19 & Paramonhystera & $\cdot$ & 1.37 & Desmodora & ${ }^{\circ}$ & 2.22 & Viscosia & 0.38 \\
\hline Halalaimus & $\cdot$ & 2.02 & Gammarinema & $\cdot$ & 1.08 & Prochromadorella & - & 2.19 & Metasphaerolaimus & 0.33 \\
\hline Southerniella & $\cdot$ & 1.74 & Diplolaimella & $\cdot$ & 0.83 & Nudora & & 1.52 & Pomponema & 0.25 \\
\hline Desmoscolex & $\cdot$ & 1.11 & Campylaimus & & 0.79 & Actinonema & $\cdot$ & 1.30 & Paramesacanthion & - $\quad 0.22$ \\
\hline Metadasynemella & & 0.75 & Theristus & $\cdot$ & 0.78 & Calomicrolaimus & • & 1.26 & Sphaerolaimus & 0.11 \\
\hline Diplopeltula & $\cdot$ & 0.63 & Ammotheristus & $\cdot$ & 0.63 & Camacolaimus & - & 1.20 & Bolbolaimus & 0.10 \\
\hline Oxystomina & $\cdot$ & 0.57 & Pandolaimus & & 0.62 & Paracanthonchus & $\cdot$ & 1.15 & Phanoderma & 0.10 \\
\hline Pareudesmoscolex & $c^{\circ}$ & 0.56 & Paralinhomoeus & $\cdot$ & 0.47 & Paranticoma & 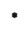 & 1.00 & Rhabdodemania & - $\quad 0.10$ \\
\hline Pselionema & $\cdot$ & 0.53 & Amphimonhystrella & • & 0.36 & Ixonema & & 0.63 & Mesacanthion & 0.07 \\
\hline Quadricoma & $\cdot$ & 0.51 & Gnomoxyala & & 0.22 & Chromadorita & & 0.59 & Enoplolaimus & 0.05 \\
\hline Rhabdocoma & $\cdot$ & 0.51 & Rhynchonema & & 0.19 & Nannolaimoides & & 0.55 & Oxyonchus & 0.05 \\
\hline Araeolaimus & $\cdot$ & 0.40 & Chaetonema & & 0.14 & Linhomoeus & ${ }^{\circ}$ & 0.38 & Batheurystomina & 0.05 \\
\hline Greeffiella & $\cdot$ & 0.37 & Elzalia & $\cdot$ & 0.12 & Chromadora & $\cdot$ & 0.31 & Doliolaimus & 0.04 \\
\hline Tricoma & $\cdot$ & 0.34 & Halanonchus & & 0.12 & Metacyatholaimus & $\cdot$ & 0.27 & Siphonolaimus & 0.03 \\
\hline Diplopeltoides & $\cdot$ & 0.29 & Metadesmolaimus & & 0.11 & Cephalanticoma & ${ }^{\circ}$ & 0.25 & Pontonema & 0.03 \\
\hline Prototricoma & $\cdot$ & 0.27 & Metalinhomoeus & $\cdot$ & 0.08 & Marylynnia & 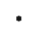 & 0.22 & Simplocostomella & 0.03 \\
\hline Aponema & $\cdot$ & 0.26 & Anticyathus & & 0.07 & Neochromadora & - & 016 & Cheironchus & 0.01 \\
\hline Thalassoalaimus & $\cdot$ & 0.26 & Megadesmolaimus & & 0.07 & Longicyatholaimus & $\cdot$ & 0.16 & Latronema & 0.01 \\
\hline Terschellingia & $\cdot$ & 0.25 & Axonolaimus & $\cdot$ & 0.07 & Pseudodesmodora & 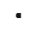 & 0.16 & Fenestrolaimus & 0.01 \\
\hline Anticoma & $\cdot$ & 0.18 & Pierrickia & & 0.07 & Spirobolbolaimus & & 0.16 & Cylicolaimus & 0.01 \\
\hline Epsilonema & $\cdot$ & 0.15 & Amphimonhystera & $\cdot$ & 0.05 & Paramesonchium & & 0.16 & Belbolla & 0.01 \\
\hline Minolaimus & " & 0.14 & Anoplostoma & $\cdot$ & 0.05 & Cobbia & • & 0.14 & Calyptronema & 0.01 \\
\hline Disconema & $\cdot$ & 0.14 & Eleutherolaimus & $\cdot$ & 0.04 & Trochamus & " & 0.11 & Eurystomina & 0.01 \\
\hline Trefusia & $\cdot$ & 0.14 & Setosabatieria & & 0.04 & Neotonchus & $\cdot$ & 0.10 & & \\
\hline Pterygonema & & 0.12 & Richtersia & & 0.03 & Crenopharynx & . & 0.08 & & \\
\hline Nannolaimus & & 0.11 & Desmolaimus & $\cdot$ & 0.03 & Chromadorella & & 0.07 & & \\
\hline Micoletzkyia & $\cdot$ & 0.11 & Eumorpholaimus & & 0.03 & Rhips & & 0.07 & & \\
\hline Litinium & $\cdot$ & 0.11 & Diplolaimelloides & & 0.01 & Vasostoma & & 0.07 & & \\
\hline Coninckia & & 0.11 & Ammotheristus aff. & $\cdot$ & 0.01 & Echinodesmodora & & 0.05 & & \\
\hline Alaimella & & 0.08 & Ascolaimus & $\cdot$ & 0.01 & Chromadorina & & 0.04 & & \\
\hline Draconema & & 0.05 & Odontophora & & 0.01 & Paralongicyatholaimus & & 0.04 & & \\
\hline Linhystera & $\cdot$ & 0.05 & & & & Dagda aff. & $\cdot$ & 0.04 & & \\
\hline Diplopeltis aff. & $\cdot$ & 0.05 & & & & Valvaelaimus & & 0.04 & & \\
\hline Phanodermopsis & $\cdot$ & 0.05 & & & & Platycoma aff. & & 0.03 & & \\
\hline Leptolaimoides & $\cdot$ & 0.04 & & & & Enchelidium & & 0.03 & & \\
\hline Setoplectus & & 0.04 & & & & Spiliphera & & 0.01 & & \\
\hline Manganonema & $\cdot$ & 0.04 & & & & Ptycholaimellus & & 0.01 & & \\
\hline Simpliconema & $\cdot$ & 0.04 & & & & Ethmolaimus & & 0.01 & & \\
\hline Diplopeltis & & 0.03 & & & & Paracyatholaimoides & & 0.01 & & \\
\hline Nemanema & & 0.03 & & & & Prochaetosoma & $\cdot$ & 0.01 & & \\
\hline Wieseria & $\cdot$ & 0.03 & & & & Hopperia & & 0.01 & & \\
\hline Dracograllus & & 0.01 & & & & & & & & \\
\hline Hapalomus & $\cdot$ & 0.01 & & & & & & & & \\
\hline Protricomoides & $\cdot$ & 0.01 & & & & & & & & \\
\hline Stephanolaimus & & 0.01 & & & & & & & & \\
\hline Tarvaia & & 0.01 & & & & & & & & \\
\hline Cyartonema & & 0.01 & & & & & & & & \\
\hline Tubolaimoides & $\cdot$ & 0.01 & & & & & & & & \\
\hline Disconema aff. & $\cdot$ & 0.01 & & & & & & & & \\
\hline Cricohalalainus & & 0.01 & & & & & & & & \\
\hline Chitwoodia & & 0.01 & & & & & & & & \\
\hline
\end{tabular}


Table 4. Percentage of selective deposit feeders (1A), nonselective deposit feeders (1B), epistratum feeders (2A) and predators/omnivores (2B) by station

\begin{tabular}{|lllll|}
\hline Stn & $1 \mathrm{~A}$ & $1 \mathrm{~B}$ & $2 \mathrm{~A}$ & $2 \mathrm{~B}$ \\
\hline K1 & 27 & 40 & 29 & 4 \\
K2 & 38 & 25 & 36 & 6 \\
K3 & 36 & 23 & 29 & 2 \\
K4 & 35 & 27 & 35 & 4 \\
K5 & 49 & 23 & 24 & 4 \\
K6 & 26 & 28 & 40 & 6 \\
H1 & 37 & 29 & 29 & 5 \\
H2 & 28 & 34 & 32 & 7 \\
H3 & 23 & 35 & 37 & 6 \\
H4 & 22 & 42 & 34 & 3 \\
H5 & 23 & 42 & 32 & 4 \\
H6 & 25 & 27 & 35 & 13 \\
H7 & 40 & 23 & 31 & 6 \\
H8 & 26 & 25 & 46 & 4 \\
H9 & 37 & 22 & 38 & 3 \\
H10 & 28 & 26 & 38 & 8 \\
H11 & 18 & 24 & 55 & 2 \\
Mean & 30 & 29 & 35 & 5 \\
Median & 28 & 27 & 35 & 4 \\
\hline
\end{tabular}

crolaimus, Paranticoma, Gammarinema, Desmoscolex, Paramonhystera, Diplolaimella, Quadricoma, Paralinhomoeus, Metasphaerolaimus, Aponema and Aegialoalaimus (mainly members of the Xyalidae, Monhysteridae, Comesomatidae, Leptolaimidae, Desmoscolecidae and Microlaimidae). For the Kapp Norvegia shelf Molgolaimus, Leptolaimus, Pandolaimus, Gnomoxyala, Metadesmolaimus, Vasostoma, Mesacanthion, Paralongicyatholaimus and Nemanema (mainly Pandolaimidae and Monoposthiidae) were recorded as TWINSPAN preferentials. Where trophic composition was highly similar between the 2 shelf communities, the number of genera per 200 ind. $\left(N_{0}\right)$ and expected genus numbers with a sample size of 100 specimens [E(G100)] were higher on the Kapp Norvegia shelf.

The shelf break, showing some faunal affinities with the Kapp Norvegie shelf by a common presence of the less dominant Nudora, Chromadorita, Draconema, Metadesmolaimus and Pandolaimus and having highly similar dominant genera with the upper slope (Fig. 4C), was composed of 2 stations (K4, H6) with very different generic composition (widely separated in CCA). Shared genera in these 2 sediments were the dominants in Fig. 4C (Sabatieria, Monhystera, Dichromadora, Acantholaimus, Molgolaimus) and the less common Paracanthonchus, Daptonema, Leptolaimus, Desmodora, Camacolaimus, and the indicator Cephalanticoma. Specific assemblages of Draconema, Eumorpholaimus, Chromadorina, Belbolla, Fenestrolaimus, Phanoderma and Richtersia typified only
Stn H6. Relatively more predators were recorded at the shelf break.

The preferential upper slope genera (from TWINSPAN) included the dominant ones in Fig. 4D, and the less abundant Ixonema, Dichromadora, Metadasynemella, Acantholaimus, Rhynchonema, Paramesonchium, Spirobolbolaimus, Chaetonema, Halanonchus, Coninckia, Trochamus, Rhips, Setosabatieria, Valvaelaimus and Pontonema (mainly Monoposthiidae, Siphonolaimidae, Pandolaimidae and Enchelididae). Chaetonema was spatially restricted to the upper slope, whereas Halichoanolaimus was completely absent.

Finally, the downslope nematodes belonged to the dominant epistrate feeders Microlaimus, Dichromadora and Acantholaimus, and to the co-dominant Monhystera, Theristus, Leptolaimus, Daptonema and the rare Batheurystomina (mainly Chromadoridae, Microlaimidae and Xyalidae).

Genus richness measures $\left[\mathrm{N}_{0}, H^{\prime}\right.$ and especially $E(G 100)$, Fig. 4 bottom] described the upper slope and shelf break as the most diverse sites and contrasted with the Halley shelf and downslope assemblages. The differences were significant ( $U$-tests on indices: Halley shelf/shelf break, Halley shelf/upper slope, downslope/shelf break, downslope/upper slope, $p<0.05)$. All other subregion combinations had a comparable structural diversity ( $U$-test, $\mathrm{p}>0.05)$, making the overall difference not significant (Kruskal-Wallis, $p>0.05$ ).

Table 5. Percentage aggregation (\%AGD) of the nematode populations at different scales in the Weddell Sea calculated by the $\chi^{2}$-statistic. The variability within the data of the individual nematode genera was tested for $(n-1)$ degrees of freedom; aggregation was assigned when $\mathrm{p}<0.025$; Regional: between the pooled stations at Halley Bay and Kapp Norvegia; Subregional: between the pooled stations of the TWINSPAN-groups; Station: between the individual stations. Tests were done on 2 types of reduced data matrices (I and II. see 'Materials and methods') ( $N$ : number of genera considered in the respective station sets)

\begin{tabular}{|c|c|c|c|c|}
\hline & $\mathrm{N}$ & $\stackrel{I}{\%} \mathrm{AGD}$ & $\mathrm{N}$ & $\begin{array}{l}\text { If } \\
\% \text { AGD }\end{array}$ \\
\hline Regional & 158 & 34 & 83 & 61 \\
\hline Halley Bay & 130 & 49 & 87 & 69 \\
\hline Kapp Norvegia & 132 & 37 & 85 & 56 \\
\hline Subregional & 158 & 51 & 83 & 78 \\
\hline Upper slope & 109 & 24 & 91 & 27 \\
\hline Downslope & 77 & 20 & 76 & 20 \\
\hline Halley shelf & 83 & 30 & 57 & 42 \\
\hline Mix & 120 & 38 & 84 & 54 \\
\hline Norvegia shelf & 93 & 29 & 73 & 38 \\
\hline Shelf break & 92 & 27 & 73 & 33 \\
\hline Station & 158 & 58 & 83 & 88 \\
\hline
\end{tabular}


Halley Bay

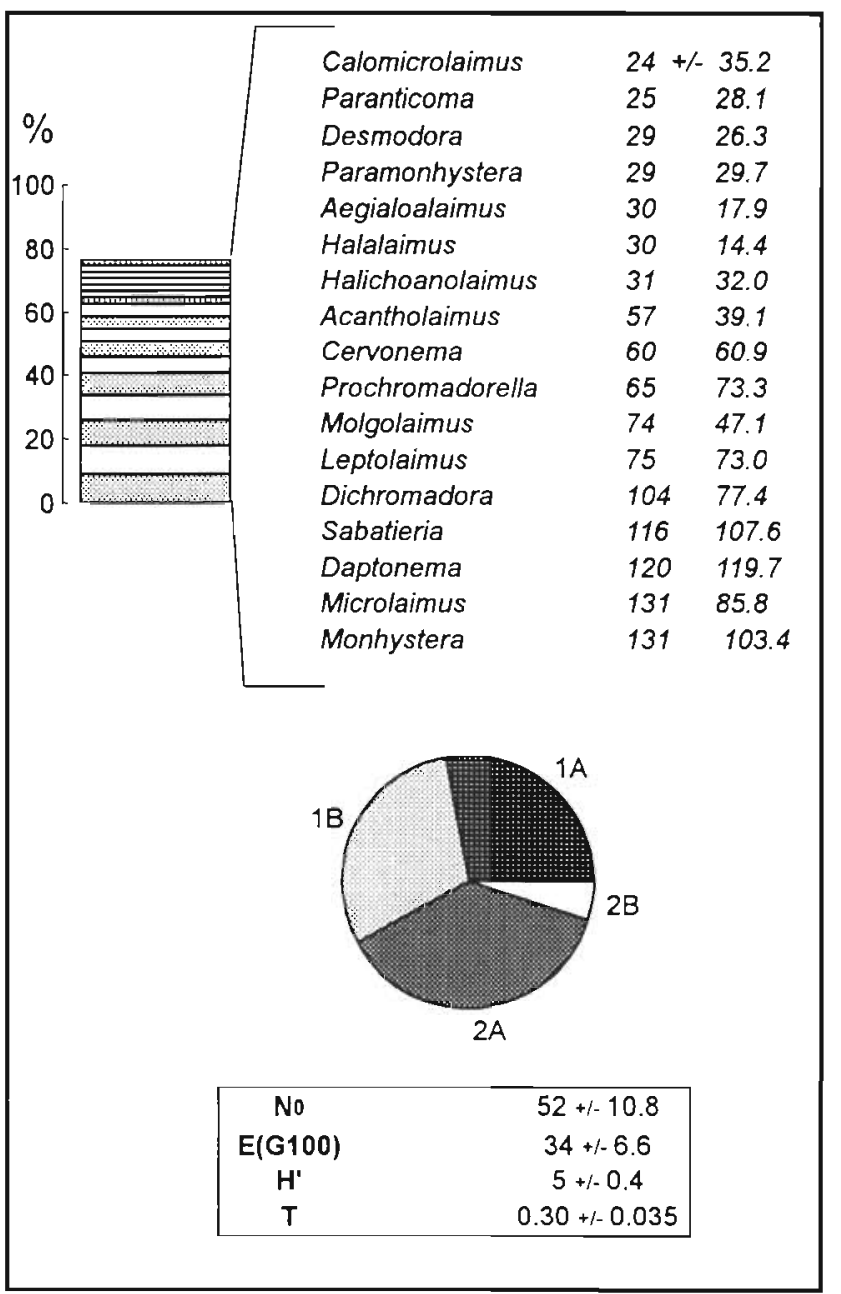

Kapp Norvegia

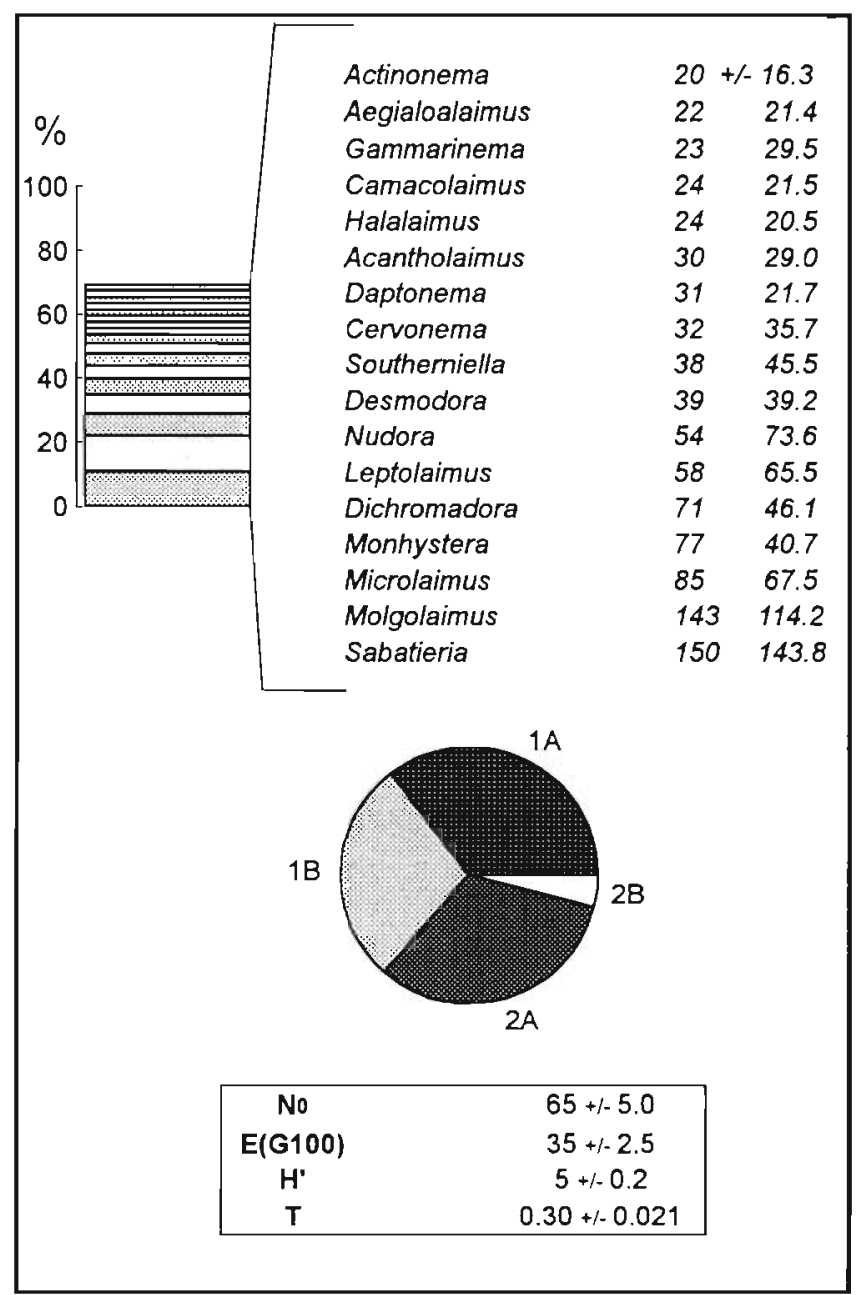

Fig. 2. Comparison on a regional scale of the nematode assemblages in the Weddell Sea: relative composition (\%) and counts (ind. $10 \mathrm{~cm}^{-2}$ ) of the genera representing on average a minimum of $2 \%$ of the regional population; trophic and age composition

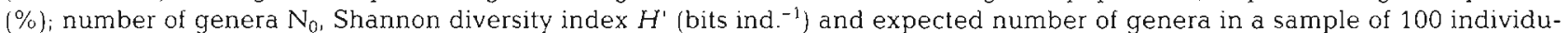
als $E(G 100)$. Data are presented as averages $( \pm S D)$ of the stations in each region. Pie diagrams represent proportions of each regional population according to trophic groups, for abbreviations see Table 4

Trophic diversity was lowest downslope $(T=0.34 \pm$ 0.057 ), which was mainly a consequence of the dominance of the epistratum feeders. Trophic diversity was only significantly different between the Halley shelf and shelf break ( $U$-test, $\mathrm{p}<0.05$ ).

$\chi^{2}$-testing on variance to mean ratios of nematode genus percentages (Table 5) detected that $51 \%$ of the total nematode community (and $78 \%$ of the dominant genera) was significantly aggregated among the subregions. The aggregation was lowest downslope (20\%) and highest in the MIX-string (38 to $54 \%$ ). The upper slope and mixed group showed the highest separation along the 2nd axis of the CCA, and confirmed greatest dissimilarity in the GAS-analysis (upper slope $45 \%$ and shelf break $43 \%$ ).

\section{Station variability}

Total variability within the genus counts, given by the $\chi^{2}$-value $(65018.6,2685 \mathrm{df})$ of variance to mean ratios, indicated a highly significant contagious dispersion at the $p=0.001$ level of the nematode populations of the Weddell Sea. Looking at different spatial scales (Table 5), this aggregated pattern was most obvious at the station level (e.g. $58 \%$ of the total nematode community and $88 \%$ of the abundant genera aggregated at particular stations). This was mainly due to the distribution of common genera like Acantholaimus, Ixonema, Nudora, Theristus, Molgolaimus, Microlaimus and Sabatieria.

Similarly, all feeding categories had on average a clumped distribution (e.g. mean and median vari- 

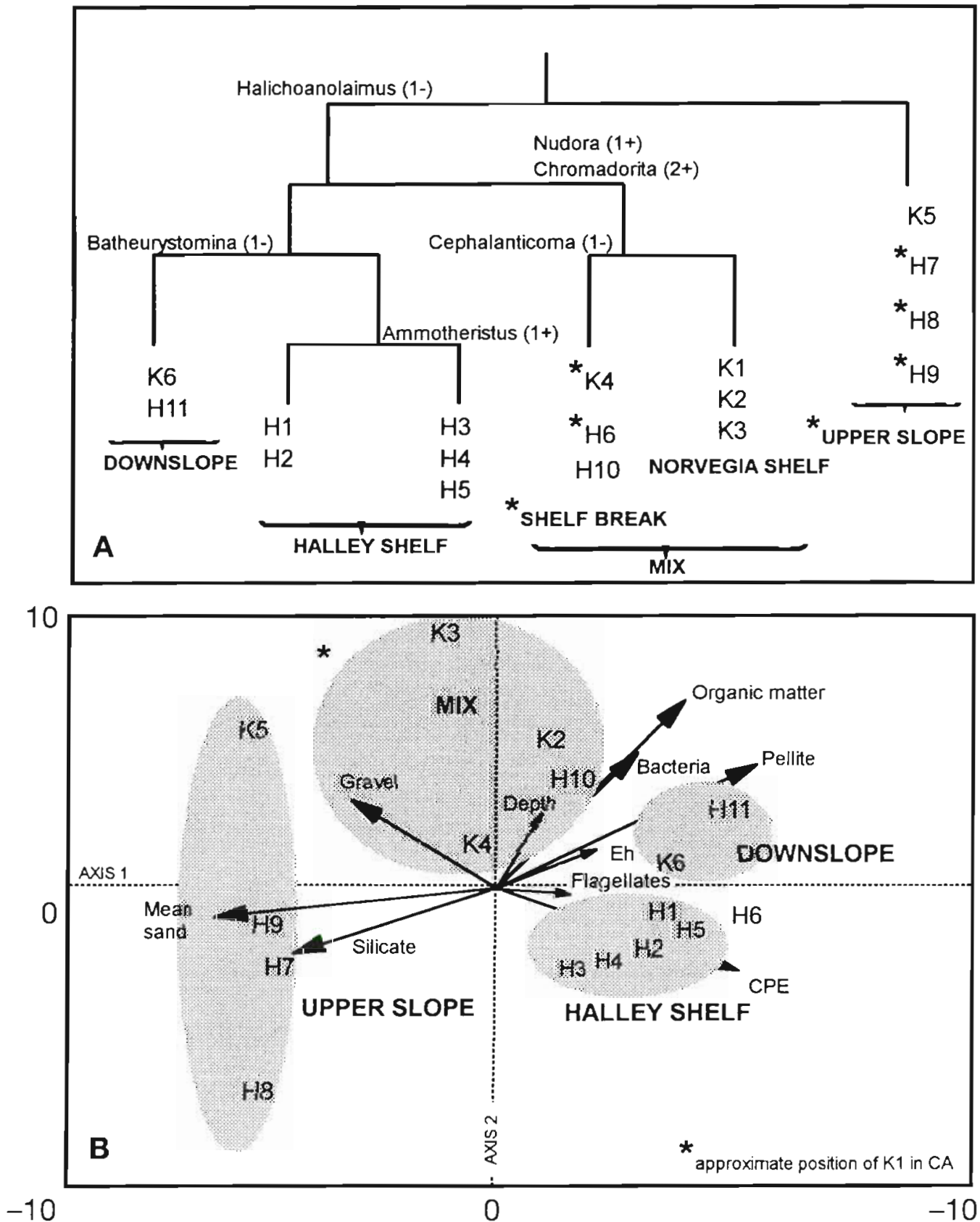

Fig. 3. Output of (A) classification (TWINSPAN with indication of indicator genera) and $(B)$ ordination (CCA environmental biplots with indication of the clusters as identified by TWINSPAN) on genus level of organization. The gradient length for the biplot of environmental variables is 3.4 times greater than the species scores. Maximum variance was $21 \%$ (Axis 1) (CPE: chloroplastic equivalents)

ance:mean ratio in Table 6 is much higher than 1), and were often patchily distributed among the replicates within the stations (e.g. significant departure from randomness at the 0.025 probability level was indicated with asterisks)

\section{Relation with environment}

On the one hand, the biplot diagrams (Fig. 3B) demonstrated that the environmental vectors did not coincide with any of the 4 first canonical axes, indi- cating low correlation of the environmental variables with the ordination plane (for example, the eigenvalues of the first 4 canonical axes of the analysis on genera were respectively $0.20,0.14,0.13$ and 0.12 , and the separation of genus distribution was 3.7 times smaller than the environmental gradients).

The results from the Spearman rank analysis between the preferentials of each subregion and the environmental variables are given in Table 7 . The majority of the upper slope populations showed significant positive correlations with median sand and opposite effects with pellite and organic matter. The Halley 


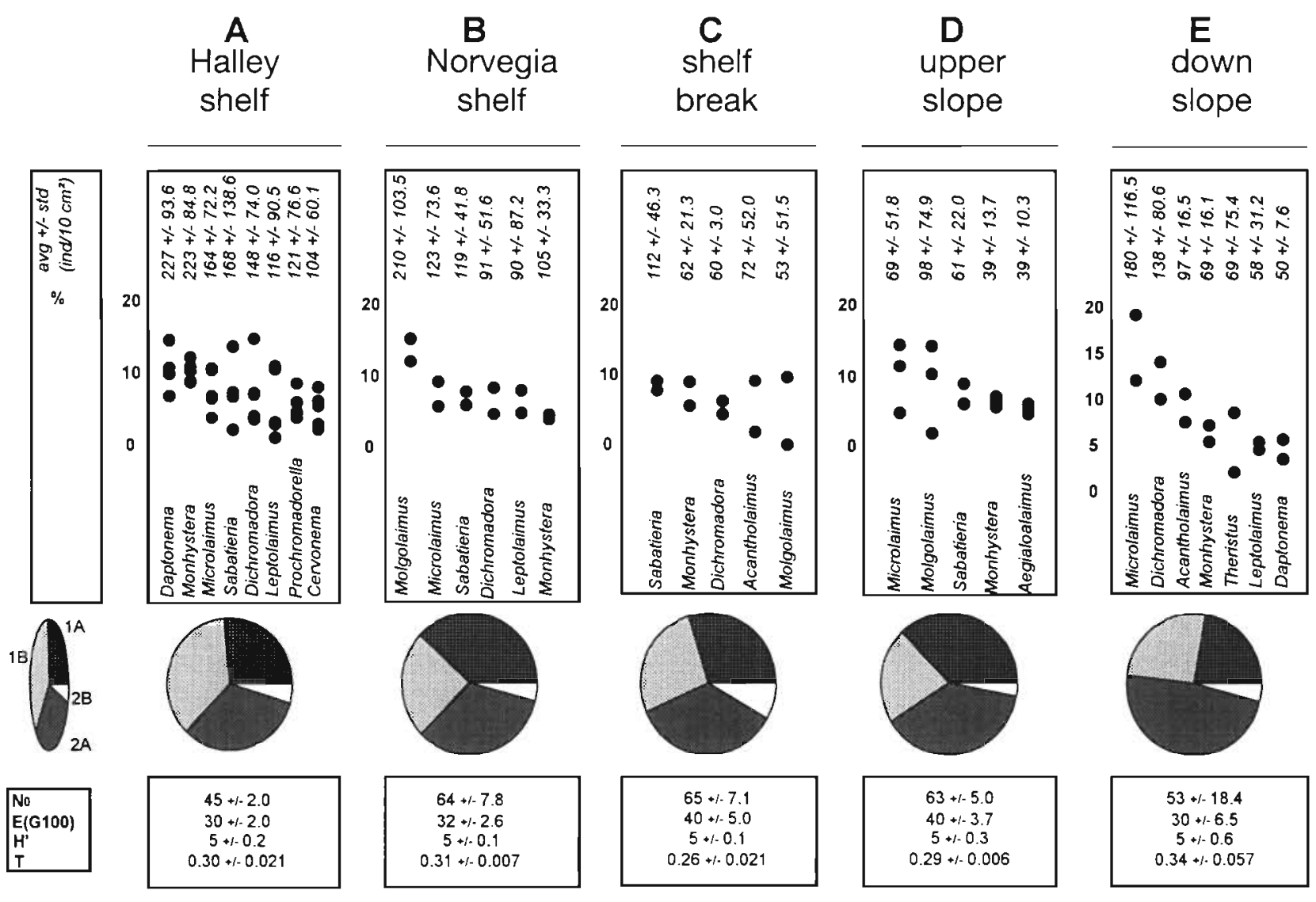

Fig. 4. Comparison on a subregional scale of the nematode assemblages in the Weddell Sea: relative composition (\%) and counts (ind. $10 \mathrm{~cm}^{-2}$ ) of the genera representing on average at least $5 \%$ of the subregional population; trophic composition (\%); number of genera $\mathrm{N}_{0}$, Shannon diversity index $H^{\prime}$ (bits ind. ${ }^{-1}$ ) and expected number of genera in a sample of 100 individuals $E(G 100$ ). Data are presented as averages $( \pm \mathrm{SD}$ ) of the stations in each subregion, except for the relative abundances of the genera where each dot represents the value per station). K1, K5 and $\mathrm{H} 10$ were not included due to their unstable position in multivariate outputs

shelf genera preferentially lived under shallow, foodrich (high $\mathrm{CPE}$, low $\mathrm{C} / \mathrm{N}$ ) circumstances, often avoiding the coarser sediment fractions, whereas downslope nematodes preferentially lived in finer sediments with low benthic biomass ( $\mathrm{p}$ was significantly negative for ATP). Water depth was not explicitly responsible for their distribution $(p>0.05$, except for Batheurystomina). The MIX-string (shelf break and Kapp Norvegia shelf) showed combined properties, often typified by higher gravel concentrations and high $\mathrm{C} / \mathrm{N}$ ratios.

Forty of the remaining genera - no pronounced indicators of any of the 4 subgroups-also showed correlations with specific environmental features (not presented). In total, $22 \%$ of all 158 nematode genera were significantly correlated with sediment granulometry, $28 \%$ with a food related-factor and only $4 \%$ with depth.

The proportion of selective deposit feeders (1A) rose when the $\mathrm{C} / \mathrm{N}$ ratios increased $(p<0.001)$, and decreased in importance with elevating CPE-leveis $(p<0.05)$. A completely opposite relation was found with the nonselective deposit feeders (e.g. p-values of $1 \mathrm{~B}$ vs $\mathrm{C} / \mathrm{N}$ and $1 \mathrm{~B}$ vs $\mathrm{CPE}$ were, respectively,
-0.004 and +0.01$)$. The epistratum feeders $(2 \mathrm{~A})$ were related to the overall sedimentary biomass given by ATP $(p<0.05)$ and the biomass of heterotrophic nanoflagellates $(\mathrm{p}<0.01)$.

\section{DISCUSSION}

\section{Comparison with nematode communities worldwide}

There seems to be a consensus among many biogeographers that the Antarctic benthic macrofauna is very old and that most of the Southern Ocean shallow-water marine fauna has evolved in situ since its isolation during the Cretaceous. This view is supported by the high level of invertebrate endemism (e.g. species endemism typically ranges between 57 and $95 \%$; genus endemism varies from 5 to $70 \%$ ) (references in Dayton 1990, Arntz et al. 1994, Knox 1994). With this in mind a TWINSPAN analysis on the limited nematode genus data available from the ocean margin was done in order to test the affinity between the deep-water assemblages from the 
Table 6. Variance: mean ratios on pooled percentage data of selective deposit feeders (1A), nonselective deposit feeders $(1 B)$, epistratum feeders (2A) and predators/omnivores (2B). Values marked with an asterisk indicate significant aggregation at the 0.025 significance level ( $\mathrm{df}=$ degrees of freedom for $\chi^{2}$-testing)

\begin{tabular}{|c|c|c|c|c|c|}
\hline Stn & $\mathrm{df}$ & $1 \mathrm{~A}$ & $1 B$ & $2 \mathrm{~A}$ & $2 \mathrm{~B}$ \\
\hline $\mathrm{K} 1$ & 2 & 1.5 & 3.6 & 1.8 & 1.4 \\
\hline $\mathrm{K} 2$ & 2 & 1.2 & 1.4 & 2.4 & $9.1^{\circ}$ \\
\hline $\mathrm{K} 3$ & 2 & 2.5 & $7.5^{\circ}$ & $4.5^{\circ}$ & 1.8 \\
\hline K4 & 3 & $13.0^{\circ}$ & $4.7^{\circ}$ & $11.1^{\circ}$ & 1.2 \\
\hline K5 & 2 & $8.2^{\circ}$ & $10.6^{\circ}$ & $5.8^{\circ}$ & 0.3 \\
\hline K6 & 2 & 0.7 & $8.6^{\circ}$ & 0.6 & 2.8 \\
\hline $\mathrm{H} 1$ & 1 & 1.2 & 2.7 & 1.2 & 8.0 \\
\hline $\mathrm{H} 2$ & 1 & 1.3 & 4.6 & 0.3 & 2.9 \\
\hline $\mathrm{H} 3$ & 1 & 0.7 & 4.5 & 0.2 & 1.8 \\
\hline $\mathrm{H} 4$ & 1 & 1.8 & 0.1 & 0.1 & 0.1 \\
\hline H5 & 1 & $6.6^{\circ}$ & $15.3^{\circ}$ & 0.6 & 3.8 \\
\hline H6 & 1 & $10.9^{\circ}$ & 4.0 & 3.1 & $5.2^{\circ}$ \\
\hline $\mathrm{H7}$ & 1 & $15.9^{\circ}$ & 0.3 & 2.7 & 3.9 \\
\hline H8 & 1 & $10.6^{\circ}$ & 0.0 & 3.1 & 3.8 \\
\hline $\mathrm{H} 9$ & 1 & 0.3 & 0.1 & 2.6 & 0.0 \\
\hline $\mathrm{H} 10$ & 1 & 2.8 & 4.4 & 4.8 & $6.3^{\circ}$ \\
\hline H11 & 1 & 1.0 & 0.1 & 0.6 & 0.1 \\
\hline Mean & & 4.7 & 4.3 & 2.7 & 3.1 \\
\hline Median & & 2.2 & 4.1 & 2.5 & 2.9 \\
\hline
\end{tabular}

Southern Ocean and other regions on the globe. The percentage data of the 20 first-ranked nematode genera from the Antarctic Weddell Sea (this study; 492 to $2080 \mathrm{~m}$ ), the Mediterranean Ligurian Sea (Soetaert et al. $1995 ; 280$ to $1220 \mathrm{~m}$ ), the Northeast Atlantic Goban Spur (Vanaverbeke et al. $1997 \mathrm{a}_{i} 206$ to $2760 \mathrm{~m}$ ) and the Arctic Laptev Sea (Vanaverbeke et al. 1997b; 230 to $3237 \mathrm{~m}$ ) were used as input. A total of 101 genera and 26 stations from the shelf break and slopes were hence included. The shallower shelf stations were ignored, as no real inner shelf exists in Antarctica (it is replaced by the iceshelf) and too few data were available from the transect studies. The resulting dendrogram in Fig. 5 shows a division into the 4 geographical areas. However this was based on 2 genera only, e.g. Dichromadora and Amphimonhystrella.

A closer look shows that $70 \%$ of the high Antarctic Weddell Sea genera with abundances over $1 \%$ match nematode assemblages in the world's oceans. Among them the predominant genera Sabatieria, Microlaimus, Monhystera, Daptonema, Leptolaimus, Molgolaimus, Dichromadora and Acantholaimus belonging to the families Chromadoridae, Comesomatidae, Microlaimidae, Monhysteridae and Xyalidae were dominant elsewhere too, albeit in different proportions. The remaining $30 \%$ were less common genera for deep water (e.g. Southerniella, Paramonhystera, Gammarinema, Desmodora, Nudora, Paracanthonchus and Halichoanolaimus), but none of them were endemic or new to science.
So, contrary to what was intuitively expected there was no sign of a relict autochthonous Antarctic nematode community, nor was there anything like a typical polar community. It is surprising that the cold Antarctic and warm Mediterranean sites were clustered together in the TWINSPAN, and even more so as the main driving forces for nematode distribution (e.g. sediment texture and food content) were not conspicuously similar to each other or different from the other sites. It remains unclear which cues other than sediment properties are responsible for the affinities between these 2 ocean margin sites.

Our comparison confirms to a certain extent earlier observations, namely, that many deep-water nematode communities are very alike irrespective of distance and only few stenotopic genera are represented (Heip et al. 1985, Thistle \& Sherman 1985, Vincx et al. 1994, Soetaert \& Heip 1995). The question is how do nematodes with their limited swimming ability reach such broad geographical and latitudinal distribution considering that they have no pelagic larval stages. A mechanism that was suggested as a possibility for meiofauna to reach suitable habitats in geographically distant areas of the deep sea is vertical transport of sediments down the shelf to greater depths and accompanying horizontal movements by near-bottom currents in the nepheloid bottom layer (Jensen 1988, 1992, Tietjen 1989). As such a mechanism acts irrespective of physiological barriers of sudden temperature, oxygen and salinity changes, deep-sea dispersion in whatever direction (north to south or opposite) combined with possible migration from deep to shallow waters might be at the origin of the widepread distribution of many meiofaunal taxa (Nematoda: Vincx et al. 1990, Copepoda: Hicks \& Coull 1983, Gastrotricha: Todaro et al. 1996). This might also hold true for the Southern Ocean, where immigration can occur via the deep basins from the Atlantic, Indian or Pacific Oceans or via shallow-water connections such as the Scotia Arc (South America), Macquarie-Balleney Ridge (Australia and New Zealand) and the Kerguelen-Gausberg Ridge (Africa and India), which rise within 1800 and $200 \mathrm{~m}$ of the surface (Knox 1994). Additional Antarctic and Subantarctic data to species level are needed to support this hypothesis

\section{World-wide comparison of nematode genus diversity}

In pioneer studies it was proposed that latitudinal gradients exist in faunal diversity, with a continuous decline in poleward direction (Fischer 1960, Pianka 1966). However, today evidence suggests that this is not a general trend (Clarke 1992, Gage 1996). Furthermore, it is widely known that most macrobenthos in Antarctica express a high species richness (Arntz et al. 1994, Brey et 
Table 7. Significant p-levels of the Spearman rank correlation between main nematode genera of each subregion in the Weddell $\mathrm{Sea}$, the overall trophic and life history traits, and environmental variables; no significant correlations were found for $\mathrm{SiO}_{2}$ or Eh (+: positive correlation, -: negative correlation, abbreviations of variables see Table 1)

\begin{tabular}{|c|c|c|c|c|c|c|c|c|c|c|}
\hline & DEPT & GRAV & MSAN & PELL & ORGM & $\mathrm{C} / \mathrm{N}$ & $\mathrm{CPE}$ & ATP & CBAK & CFLAG \\
\hline \multicolumn{11}{|l|}{ GENERA } \\
\hline \multicolumn{11}{|l|}{ Upper slope } \\
\hline Chaetonema & & & & $0.004(-)$ & $0.02(-)$ & & & & & \\
\hline Coninckja & & & $0.05(+)$ & $0.02(-)$ & & & & & & \\
\hline Halanonchus & & & $0.05(+)$ & $0.02(-)$ & & & & & & \\
\hline Ixonema & & & $0.05(+)$ & $0.001(-)$ & $0.05(-)$ & & & & & \\
\hline Metadasynemella & & & $0.03(+)$ & $0.05(-)$ & $0.03(-)$ & & $0.03(-)$ & & & \\
\hline Paramesonchium & & & & $0.005(-)$ & $0.02(-)$ & & & & & \\
\hline Rhynchonema & & & $0.005(+)$ & $0.0001(-)$ & $0.004(-)$ & & & & & \\
\hline Spirobolbolaimus & & $0.03(+)$ & $0.02(+)$ & & & & & $0.03(-)$ & & \\
\hline Trochamus & & & $0.007\{+\}$ & $0.01(-)$ & $0.0007(-)$ & & & & $0.02(-)$ & \\
\hline \multicolumn{11}{|l|}{ Halley shelf } \\
\hline Calomicrolaimus & $0.05(-)$ & & & & & & $0.05(+)$ & & & \\
\hline Daptonema & & $0.02(-)$ & $0.03(-)$ & & & $0.005(-)$ & & $0.01(-)$ & & \\
\hline Desmoscolex & $0.009(-)$ & & & & & & & & & \\
\hline Diplolaimella & & & & & & $0.03(-)$ & & & & \\
\hline Gammarinema & $0.02(-)$ & & & & & & & & & $0.01(+)$ \\
\hline Leptolaimus & & & $0.02(-)$ & & $0.05(+)$ & & & & & \\
\hline Metasphaerolaimus & $0.02(-)$ & & & & & $0.04(-)$ & $0.02(+)$ & & & \\
\hline Monhystera & & & & & & $0.004(-)$ & $0.05(+)$ & & & \\
\hline Paralinhomoeus & & & & $0.001(-)$ & $0.003(-)$ & & & & & \\
\hline Prochromadorella & & & & & & $0.0001(-)$ & $0.004(+)$ & & & \\
\hline \multicolumn{11}{|l|}{ Downslope } \\
\hline Acantholaimus & & & $0.007(-)$ & & & & & & & \\
\hline Batheurystomina & $0.02(+)$ & & $0.05(-)$ & $0.02(+)$ & & & & $0.05(-)$ & & $0.05(-)$ \\
\hline Gammanema & & $0.002(+)$ & $0.02(+)$ & & & & & & & \\
\hline Theristus & & & & & & & & $0.02(-)$ & & \\
\hline \multicolumn{11}{|l|}{ Mix } \\
\hline Draconema & & $0.03(+)$ & & & & & & & & \\
\hline Metadesmolaimus & & & & & $0.005(+)$ & & & & & \\
\hline Nudora & & & & & & $0.00004(+)$ & & & & \\
\hline Pandolaimus & & $0.005(+)$ & $0.03(+)$ & & & $0.008(+)$ & & & & \\
\hline \multicolumn{11}{|l|}{ TROPHIC GROUP } \\
\hline $\begin{array}{l}\text { Selective deposit } \\
\text { feeders (1A) }\end{array}$ & & & & & & $0.001(+)$ & $0.04(-)$ & & & \\
\hline $\begin{array}{l}\text { Nonselective deposit } \\
\text { feeders (1B) }\end{array}$ & $0.04(-)$ & & & & & $0.004(-)$ & $0.01(+)$ & & & \\
\hline Epistratum feeders (2A) & & & & & & & & $0.03(-)$ & & $0.002(-)$ \\
\hline Predatores/omnivores (2B) & & & & & & & & & & \\
\hline
\end{tabular}

al. 1994). Comparing nematode diversity on ocean-wide scales is difficult, primarily because of the lack of species identifications in meiofaunal, deep-sea studies, and also because of the high sample size dependence of many diversity indices (Soetaent et al. 1991). Therefore we restricted to the same depth transect studies mentioned above (Fig. 5), which, except for the Atlantic, used the same subsample sizes (see $\mathrm{N}$ in lowermost columns). All diversity measures were based on genus data. Antarctic diversity was not remarkably different from Atlantic or Mediterranean diversity. However, a distinct contrast was obvious between the North (ARC) and South (ANT) Polar Seas. Although still a matter of debate (Strömberg 1996), productivity might have been one of the many driving forces contributing to this striking difference in diversity between the polar seas. In contrast to the Antarc- tic (see later section), the area of the nematode study in the Arctic Ocean (Laptev Sea) experienced limited primary production and a large reduction in the supply of degradable organic matter to the benthos (references in Vanaverbeke et al. 1997b). Other factors that might have shaped Antarctic diversity are for example higher age, greater environmental constancy and longer isolation (Brey et al. 1994).

The factors depth, sediment and food in the environmental control of nematode distribution at the station scale

The pooled $\chi^{2}$-tests proved for a great sampling accuracy with a random distribution of the nematodes 

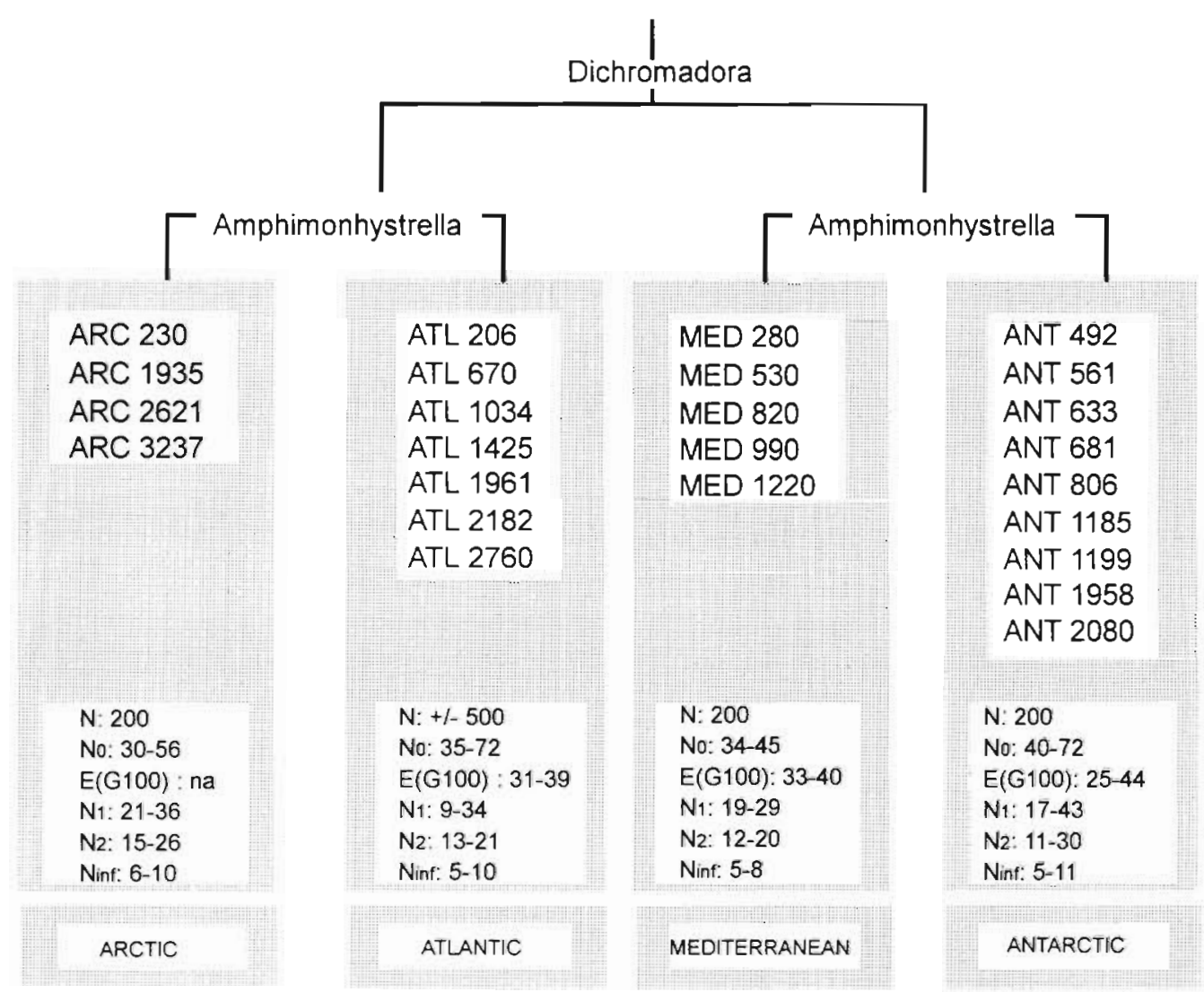

Fig 5 TWINSPAN analysis on the 20 furst-ranked genera (nontransformed percentage datal in 4 transects along the continental margin. together with Hill's diversity numbers and, if given, the expected number of genera from Hurlbert's modification on Sanders' rarefaction curves (ranges along the transect) (ARC: Arctic Laptev Sea [Vanaverbeke et al. 1997b], ATL Northeast Atlantic Goban Spur [Vanaverbeke et al. 1997a], MED. Mediterranean Ligurian Sea [Soetaert et al 1995], ANT. Antarctic Weddell Sea [this study]) The numbers indicate water depth along the transect, indicator species are added, cutlevels used. 0, 1.7; $2.6 ; 48 ; 51$ Hill's diversity numbers $\left(\mathrm{N}_{0}\right.$ : number of genera, $\mathrm{N}_{1}$ the exponent of the Shannon-Wiener diversity index; $\mathrm{N}_{2}$ : the reciprocal of Simpson's dominance index, $N_{\text {inf }}$ the reciprocal of the relative abundance of the most abundant genus)

among the replicates. However, we found a high degree of aggregation ( 58 to $88 \%$ ) in the genus numbers between the total set of stations and a high natural between-core variability for deposit and epistratum feeders. Patchiness in nematode communities is a common phenomenon in all kinds of habitats (Help et al. 1985, Li et al. 1997), and variability on a small scale is also apparent in deep-sea meiofauna (Thistle 1978, Thiel 1983, Eckman \& Thustle 1988) The complex of environmental properties such as sediment texture and food content might have created an intncate mosaic of local patches leading to the small-scale vanability (within metres) in the Antarctic biogeochemical environment and thus in nematode distribution.

Fifty percent of the genera were significantly correlated with sedıment granulometry and/or food; although not explicitly distinguished by the results, this seems the probable ongin of the surprisingly high abundances of epistrate feeders sensu Wieser (1953) Simular observations were made in the Norwegian Sea (Jensen 1988), in heterogeneous sediments of the
Venezuela Basin (Tietjen 1984) and on the Hatteras abyssal plain (Tietjen 1989). According to Wieser (1953) members from this trophic category pierce or swallow entire diatoms, and/or rasp off microbial coatings around foraminiferan tests, clumps of bacterla and other organic particles from sediment grains. But they were also related to planktonic foraminiferal deposition (Tietjen 1984, 1989, Jensen 1988). In the Weddell Sea epistrate feeders were positively correlated with microbial (ATP) and protozoan biomass (flagellates). Protozoa are a food source that has been underestimated up to now, but one that has been used to nourish a separate group of deposit teeders (ciliate feeders) on an intertdal mudflat sensu Moens \& Vincx (1997).

Selective deposit feeding or microvory was positively correlated with decomposing material (e.g with $\mathrm{C} / \mathrm{N}$ ratios between 7 and 9, Tyson 1995) and dominated the Kapp Norvegia shelf and Halley upper slope. Presumably, these substrates were stıll a good medium for the growth of many microorganisms (such as bacteria and fungi) and therefore attractive to selective 
microvores at these sites. Nonselective deposit feeding, on the other hand, was related to the highly abundant fresh organic matter (CPE) on the Halley shelf. Hence, nonselectivity prevailed over selectivity in circumstances of excess fresh labile detritus, whereas the contrary held in sediments where selectivity was needed for distinguishing between particles in different stages of decomposition.

All the pieces together raise questions concerning the ecological significance of the 4 feeding categories sensu Wieser (1953) for nematode assemblages in deep water. A new trophic classification based on natural history and dietary specialization of nematodes in this biotope might be considered.

\section{Features inducing variability in Antarctic nematode populations at the regional and subregional scales}

\section{Macrobenthic zonation}

The benthos on the shelf of the eastern Weddell Sea, with respect to biomass and abundance, appears to be fairly rich in fauna, with a considerable variability in the small- and large-scale distributions (Gerdes et al. 1992). Based on a comprehensive inventory of the macrobenthos of the area, Voß (1988) separated an eastern shelf, a southern shelf and a southern trench community. In addition, Galéron et al. (1992) characterized a 4 th macrofaunal assemblage that points to the importance of ice-related processes as agents for structuring Antarctic benthos. It was defined as the near ice-shelf community.

The eastern shelf community, within the confines of the Antarctic Coastal Current in the east, on unsorted sediments at depths between 204 and $445 \mathrm{~m}$, is highly diversified and dominated by suspension feeding sponges (Hexactinellida and Demospongia), bryozoans, echinoderms, crinoids and ophiuroids (Hain 1990, Gutt 1991, Galéron et al. 1992, Hempel 1992). Many of these organisms produce thick mats of spicules and debris which may locally be over $1 \mathrm{ml}$ thick (Dayton 1990). The sponges and their biogenic sediments influence the distribution of smaller fauna in many ways: they (1) inhibit the feeding activities of predators; (2) trap phytodetrital material such that the food supply near the sediment-water interface is enhanced; (3) provide an excellent 3-dimensional substratum for algal, bacterial and meiofaunal assemblages as they are composed of many interstitial spaces; or (4) fulfill a rôle as habitat stabilizer by reducing sediment agitation (Bett \& Rice 1992, Tyler 1995, Witte et al. 1997). Stations inhabited by the eastern shelf community included most stations from Kapp Norvegia (K1 to K4) and the 3 upper slope stations off
Halley Bay ( $\mathrm{H} 7, \mathrm{H} 8, \mathrm{H} 9)$ although the latter group was situated on the border between the southern and eastern shelf communities (Galéron et al. 1992, their Fig. 3\}. Many genera were found in high numbers, hence giving rise to diverse nematode assemblages. For example, K2-sediments were covered with thick spicule mats from hexactinellid sponges (Boldrin unpubl. results). Molgolaimus, Sabatieria, Leptolaimus, Dichromadora, Desmodora and Cervonema typified the community and the 2nd highest genus and family numbers were found at this site.

The southern shelf community, on sandy and soft bottoms strewn with stones at depths between 220 and $531 \mathrm{~m}$, supports a more diverse group of motile pycnogonids, echinoids, asteroids, holothurians, peracarids, polychaetes and shrimps (Hain 1990, Gutt 1991, Galéron et al. 1992, Gerdes et al. 1992, Hempel 1992). Halley Bay provides a habitat for this community (Galéron et al. 1992, their Fig. 3), which includes continental margin fauna with ubiquitous genera from the Monhysteridae (Monhystera), Microlaimidae (Microlaimus), Xyalidae (Daptonema), Comesomatidae (Sabatieria) and Chromadoridae (Dichromadora) (Soetaert \& Heip 1995). Seemingly, this community consists of nematode genera that easily adapt to the patchy distribution of the motile macrofauna.

The southern trench community is situated south of the current area of investigation and no characteristic near ice-shelf community could be recognized.

\section{Production}

Production in the pelagial and delivery of food to the seabed have been mentioned several times as main factors influencing the size and structure of the benthos (Pearson \& Rosenberg 1987), and particularly the deep-sea benthos (Thiel 1975). The high standing stocks of meiofauna in a related study (Vanhove et al. 1995) similarly supported the importance of overhead production; high upwelling values were persistently recorded and immense quantities reached during certain events in austral summer (to $2342 \mathrm{mg} \mathrm{C} \mathrm{m}^{-2} \mathrm{~d}^{-1}$ in the coastal zone, Bathmann et al. 1991; with an average summer production of $557 \mathrm{mg} \mathrm{C} \mathrm{m} \mathrm{m}^{-2} \mathrm{~d}^{-1}$, JarreTeichmann et al. 1997). The settlement of large amounts of organic matter possibly led to an overall high trophic and structural diversity along the transect. The slight prominences of certain genera and trophic types in the various subregions (see earlier discussion) could be attributed to a different origin of available food (e.g. $1.5 \%$ of depositing matter in traps during austral summer in the SE Weddell Sea is chlorophyll a and $0.5 \%$ particulate organic carbon, of which 60 to $90 \%$ originates from faecal pellets of diatoms and pro- 
tozoan heterotrophic flagellates, ciliates, radiolarians and foraminifers, Nöthig 1988).

\section{Hydrodynamic regime}

The Weddell Sea gyre primarily demarcates the study area (Hellmer \& Bersch 1985, Fahrbach et al. 1992), and upwelling phenomena were reinforced by strong northeasterly wind gales predominating the environment prior to the sampling period (Rohardt et al. 1990). The influence was most obvious on the upper continental slope, where current velocity could be as high as $50 \mathrm{~cm} \mathrm{~s}^{-1}$ (Bathmann et al. 1991). This resulted in lateral advection and resuspension in which bedload transport prevented sedimentation of finer fractions (Rabitti et al. 1990) and fresh phytodetritus (e.g. in $\mathrm{H} 9 \mathrm{C} / \mathrm{N}$ ratios were highest and CPE content was among the lowest). Sedimentdwelling macrofauna are particularly vulnerable to disturbance induced by the hydroregime (Gage 1996). The sediments were scarce in macro-infauna but supported discrete aggregations of porifers, holothurians and pycnogonids (Galéron et al. 1992, Gerdes et al. 1992). However, as the upper few millimetres of sediment may be completely stripped because of high currents, it is certainly possible that currents have a high impact on the meiofauna too. Our results demonstrated a low affinity among the stations located in this high-energy biotope. Nematodes often belonged to rare genera like Ixonema, Rhynchonema, Metadasynemella, Paramesonchium, Spirobolbolaimus, Chaetonema, Halanonchus, Coninckia, Trochamus, Rhips, Setosabatieria, Valvaelaimus and Pontonema. Many of these genera have morphological adaptations such as long tails, large body sizes and long setae. Although such functional adaptations might be specific for rigorous current regimes (e.g. to feed toward the surface and to avoid resuspension, Tietjen 1976, Thistle \& Sherman 1985), they can also be related to the substrate strictu senso (e.g. the hydrodynamically active biotopes often have coarse-grained sediments).

\section{Icebergs}

A hummocky seabed morphology on the continental shelf indicated considerable impact of grounding icebergs in the eastern region of the Weddell Sea (Lien et al. 1989). The resulting plough marks (with average widths of 30 to $70 \mathrm{~m}$ and reliefs from 15 to $30 \mathrm{~m}$ ) characterized the ice-rafted sediments as poorly sorted sands with varying content of gravel and pebbles and a depletion of the finest grain fractions (for example K3 and K4). In localities where the physical compaction was high, variations in grain size distribution lead to a down-core trend of increasing sediment density with a deep black colour and decreasing water content (Vanhove pers. obs.). In situ surveys demonstrated that iceberg grounding caused considerable damage to macrobenthic communities in Kapp Norvegia, affecting spatial scales from tens of metres to many kilometres (Gutt et al. 1996). However, there was no indication of a deleterious effect on meiobenthic communities. This is not surprising because during the sampling no fresh (i.e. of the previous few days) scour was hit. As nematodes are amongst the most resilient organisms, with relatively short generation times which allow rapid response to environmental changes, a clear effect of iceberg activity is only expected within a very short period after scouring (Heip et al. 1985). Nevertheless, the grouping of the Kapp Norvegia shelf stations suggests that as a consequence of the more frequent disturbance by iceberg scouring in the area (e.g. once every $230 \mathrm{yr}$, Gutt et al. 1996), a specifically adapted nematode assemblage evolved with $\mathrm{Mol}$ golaimus as a dominant genus. Molgolaimus is also often common in reduced habitats such as hydrothermal vents and hypoxic muds (Vanreusel et al. 1997 and included references).

\section{The shelf break}

The results showed that the shelf break occupied an unstable positioning in the multivariate outputs (Fig. 3). Apart from the common genera Sabatieria, Monhystera, Dichromadora, Acantholaimus and Molgolaimus, the sediments of the 2 shelf break stations expressed a very low affinity, and many rare genera like Draconema, Eumorpholaimus, Chromadorina, Belbolla, Fenestrolaimus, Phanoderma and Richtersia were present. Therefore we could not easily distinguish a typical shelf break association. The most straightforward argument is probably the great difference in sedimentological properties at the 2 stations representing this subregion (e.g. $\mathrm{K} 4$ and $\mathrm{H} 6$, Table 1 , Fig. 3B). These are, in turn, a function of the distinct shape of the entire transition zone between the coast and the deep sea (e.g. shelf widths, slope declines and water regimes are completely different, Hellmer \& Bersch 1985, Fahrbach et al. 1992).

Of interest was also the greater proportion of predators. The guts of Halichoanolaimus and Gammanema included undigested sclerotized elements of the copulatory apparatus of the nematode Desmodorella, substantiating their rôle as predators. A similar situation has also been noted in Mediterranean canyons, and was attributed to the presence of labile organic matter (e.g. more labile organic matter induces a more complex trophic food web with relatively more predators, Soetaert et al. 1995) 
The link between the Antarctic nematode community structure and disturbance

For a number of reasons nematode assemblages offer a potential means of assessing disturbance: nematodes are abundant; they are found in almost all environmental conditions which can support metazoan organisms; as permanent members of the benthos, they are unable to escape from disturbance stimuli; they have a relatively rapid turnover compared to the macrofauna, so that the composition of the nematode fauna can react rapidly to disturbances (Heip et al. 1985). Therefore we selected the 2 following characteristics of the Antarctic nematode community to deduce the level of natural disturbance in the Weddell Sea.

(1) Lambshead \& Hodda (1994) suggested that the impact of disturbance on nematode populations can be measured by analyzing variance to mean ratios in the distribution patterns. One of their hypotheses was that more species in a deep-sea community are significantly aggregated in a more disturbed system. Our results (Table 5) gave in descending order of aggregation: Halley shelf ( 30 to $42 \%$ ), Kapp Norvegia shelf $(29$ to $38 \%$ ), shelf break (27 to $33 \%)$, upper slope (24 to $27 \%$ ) and downslope (20\%). If spatial variability is indeed a measure of disturbance, this means that the shelf off Halley Bay is the locality of highest disturbance, whereas the downslope sediments of the same region are the least impacted by disturbance activity.

(2) Bongers et al. (1991) suggested that the nematode Maturity Index (MI) may be useful in assessing disturbance of marine sediments. When nematodes are categorized according to their life strategy and are assigned a value ranging from colonizer (usually $r$-strategists with value 1) to persister (generally $K$-strategists with value 5 ), the $\mathrm{MI}$ is the weighted mean of the individual taxon scores. The lower the MI the more disturbed the region. When calculating the MI on the genera presented in Fig. 4, a disturbance gradient arises, in descending order. Halley shelf $(\mathrm{MI}=1.83)$, downslope $(\mathrm{MI}=1.89)$, shelf break $(\mathrm{MI}=1.93)$, Kapp Norvegia shelf $(\mathrm{MI}=2.18)$ and upper slope $(\mathrm{MI}=2.34)$.

The disturbance gradient obtained from the aggregation theory is not always in agreement with the gradient from the Maturity Index. This demonstrates that each disturbance stimulus has a different effect on the distribution and composition of the nematode populations in the Weddell Sea. This effect can be dependent on the time-scale of nematode response. Perhaps a few hours to a couple of days are enough to change aggregation patterns, whereas the establishment of a community becomes manifest only on a longer time scale.

\section{Concluding remarks}

In contrast to the high degree of macrofaunal endemism there is no sign of an autochthonous Antarctic nematode community. Instead the assemblages are composed of similar predominant genera as elsewhere along the world's continental margins, hence expressing comparable high diversity. The communities in the eastern Weddell Sea are organized in 4 major groups (e.g. Kapp Norvegia shelf, Halley Bay shelf, upper slope and downslope), and lack a gentle cline from the shallow to the deep. There was no typical shelf break association. Sediment texture and food content are put forth to explain variability in the nematode distribution at the station scale. Suggested features inducing variability at the regional and subregional scale are productivity, hydrodynamic regime, ice-related processes and macrofaunal occurrence

Acknowledgements. The research presented in this paper was performed under the auspices of the Scientific Research Programme on Antarctica-Phase III and IV from the Belgian State-Prime Minister's Federal Office for Scientific, Technical and Cultural Affairs (DWTC) and the University of Gent (contract BOF 98-03, 12050398). Prof. Dr A. Coomans (University of Gent) kindly provided the research facilities. Samples were collected during the European 'Polarstern' study (EPOS) sponsored by the European Science Foundation and the Alfred Wegener Institute for Polar and Marine Research, Germany. We are indebted to the officers and the crew of RV 'Polarstern' for their careful deployment of coring equipment, under the supervision of Dr D. Gerdes and Dr R. L. Herman. We are also grateful to $G$. Desmet for mounting the nematodes. Finally, we acknowledge the many readers for stimulating comments on earlier versions of the manuscript. The complete nematode datasets (Excel spreadsheets) are available on request

\section{LITERATURE CITED}

Arntz WE, Gallardo VA (1994) Antarctic benthos: present position and future prospects. In: Hempel $G$ (ed) Antarctic science. Springer-Verlag, Berlin, p 243-277

Arntz W, Ernst W, Hempel I (1990) The Expedition ANTARKTIS VII/4 (Epos leg 3) and VII/5 of RV 'Polarstern' in 1989 Ber Polarforsch 68:1-214

Arntz WE, Brey T, Gallardo VA (1994) Antarctic zoobenthos Oceanogr Mar Biol Annu Rev 32:241-304

Bathmann UV, Fisher G, Müller PJ, Gerdes G (1991) Shortterm variation in particulate matter sedimentation off Kapp Norvegia, Weddell Sea, Antarctica: relation to water mass advection, ice cover, plankton biomass and feeding activity. Polar Biol 11(3):185-195

Bett BJ, Rice AL (1992) The influence of hexactinellid sponge (Pheronema carpenteri) spicules on the patchy distribution of macrobenthos in the Porcupine Seabight (bathyal NE Atlantic). Ophelia 36(3):217-226

Blanchard GF (1990) Overlapping microscale dispersion patterns of meiofauna and microphytobenthos. Mar Ecol Prog Ser 74:99-107

Bongers T, Alkemade R, Yeates GW (1991) Interpretation 
of disturbance-induced maturity decrease in marine nematode assemblages by means of the Maturity Index. Mar Ecol Prog Ser 76:135-142

Bray JR, Curtis JT (1957) An ordination of the upland forest communities of southern Wisconsin. Ecol Monogr 27: $325-349$

Brey T, Klages M, Dahm C, Gorny M, Gutt J, Hain S, Stiller M, Arntz WE, Wägele J-W, Zimmerman A (1994) Antarctic benthic diversity. Nature (Lond) 368:297

Bussau C (1993) Taxonomische und ökologische Untersuchungen an Nematoden des Peru-Beckens. PhD thesis, University Kiel

Clarke A (1992) Is there a latitudinal cline in the sea? Trends Ecol Evol $7(9): 286-287$

Cody ML (1986) Diversity, rarity, and conservation in Mediterranean-climate regions. In: Soule, ME (ed) Conservation biology: the science of scarcity and diversity. Sinauer, Sunderland, MA, p 122-152

Dayton PK (1990) Polar benthos. In: Smith WO (ed) Polar oceanography, Part B: chemistry, biology, and geology. Academic Press, London, p 631-685

de Bovée F (1987) Dynamique des nématodes profonds. Structures quantitatives et dimensionelles. In: Collogne International d'Oceanologie: Ecosystemes Marges Continentales. Commission Internationale pour l'Exploration Scientifigue de la Mer Mediterranee, Monaco, p 1-69

Dinet A, Vivier MH (1979) Le méiobenthos abyssal du Golfe de Gascogne. II Les peuplements de nématodes et leur diversité spécifique. Cah Biol Mar 20:109-123

Eckman JE. Thistle D (1988) Small-scale spatial pattern in meiobenthos in the San Diego Trough. Deep-Sea Res 35(9): 1565-1578

Fahrbach E, Rohardt G, Krause G (1992) The Antarctic Coastal Current in the southeastern Weddell Sea. Polar Biol 12:171-182

Fischer AG (1960) Latitudinal variation in organic diversity. Evolution 14:64-81

Gage JD (1996) Why are there so many species in deep-sea sediments? J Exp Mar Biol Ecol 200:257-286

Galéron J, Herman RL, Aranud PM, Arntz WE, Hain S, Klages M (1992) Macrofaunal communities on the continental shelf and slope of the southeastern Weddell Sea, Antarctica. Polar Biol 12:283-290

Gerdes D, Klages M, Arntz WE, Herman RL, Galéron J, Hain S (1992) Quantitative investigations on macrobenthos communities of the southeastern Weddell Sea based on multibox corer samples. Polar Biol 12:291-301

Gourbault N, Boucher G (1981) Nématodes abyssaux (Campagne Walda du N/O 'Jean Charcot') Une sous-famille et six espèces nouvelles de Sphaerolaimidae. Bull Mus Natl Hist Nat Paris 4(3), A(4): 103.5-1052

Gray JS, Poore GCB, Ugland KI, Wilson RS, Olsgard F, Johannessen $\varnothing$ (1997) Coastal and deep-sea diversities compared. Mar Ecol Prog Ser 159:97-103

Grobe H (1986) Spätpleistozäne Sedimentprozesse am antarktischen Kontinentalhang vor Kapp Norvegia, östliche Weddell See. Ber Polarforsch 27:1-121

Gutt J (1991) On the distribution and ecology of holothurians in the Weddell Sea (Antarctica). Polar Biol 11:145-155

Gutt J, Starmans A, Dieckmann G (1996) Impact of iceberg scouring on polar benthic habitats. Mar Ecol Prog Ser 137: $311-316$

Hain S (1990) The benthic seashells (Gastropoda and Bivalvia) of the Weddell Sea, Antarctica. Ber Polarforsch 70 : $1-181$

Hall SJ, Raffaelli D, Thrush SF (1994) Patchiness and distribution in shallow water benthic assemblages. In: Giller
PS, Hildrew AG, Raffaelli DS (eds) Aquatic ecology, scale, pattern and process. Blackwell Scientific, Oxford p $333-375$

Heip C, Herman R, Vincx M (1984) Variability and productivity of meiobenthos in the Southern Bight of the North Sea. Rapp P-V Réun Cons Int Explor Mer 183:51-56

Heip C, Vincx M, Vranken G (1985) The ecology of marine nematodes. Oceanogr Mar Biol Annu Rev 23:399-489

Heip C, Herman PMJ, Soetaert K (1988) Data processing, evaluation and analysis. In: Higgins RP, Thiel $H$ (eds) Introduction to the study of meiofauna. Smithsonian Institution Press, Washington, DC, p 197-231

Hellmer HH, Bersch M (1985) The Southern Ocean. Ber Polarforsch 26:1-115

Hempel G (1992) Weddell Sea: a high polar ecosystem. In Sherman K, Alexander LM, Gold BD (eds) Large marine ecosystems: patterns, processes and yields. American Association for the Advancement of Science, Washington DC, p 5-18

Herman RL, Dahms HU (1992) Meiofauna communities along a depth transect off Halley Bay (Weddell Sea-Antarctica). Polar Biol 12:313-320

Hicks GRF, Coull BC (1983) The ecology of marine meiobenthic harpacticoid copepods. Oceanogr Mar Biol Annu Rev $23: 67-175$

Higgins RP. Thiel H (1988) Introduction to the study of meiofauna. Smithsonian Institution Press, Washington, DC

Hill MO (1979) TWINSPAN - A FORTRAN program for arranging multivariate data in an ordered two-way table by classification of the individuals and attributes. Ecology and Systematics, Cornell University, Ithaca, NY

Hurlbert SH (1971) The nonconcept of species diversity: a critique and alternative parameters. Ecology 52(4):577-586

Jarre-Teichmann A, Brey T, Bathmann UV, Dahm C, Dieckmann GS, Fgorny M, Klages M, Pagés F, Plötz J, SchanckSchiel SB, Stiller M, Arntz WE (1997) Trophic flows in the benthic shelf community of the eastern Weddell Sea, Antarctica. In: Battaglia B, Valencia J, Walton DHW (eds) Antarctic communities: species, structure and survival. Cambridge University Press, Cambridge, p 118-134

Jensen $P$ (1988) Nematode assemblages in the deep-sea benthos of the Norwegian Sea. Deep-Sea Res 35:1173-1184

Jensen P (1992) Predatory nematodes from the deep-sea: description of species from the Norwegian Sea, diversity of feeding types and geographical distribution. Cah Biol Mar 33:1-23

Knox GA (1994) The biology of the Southern Ocean. Studies in polar research. Cambridge University Press, Cambridge

Lambshead PJD, Hodda M (1994) The impact of disturbance on measurements of variability in marine nematode populations. Vie Milieu 44(1):21-27

Li J, Vincx M, Herman PMJ, Heip C (1997) Monitoring meiobenthos using $\mathrm{cm}-$, $\mathrm{m}$ - and $\mathrm{km}$-scales in the Southern Bight of the North Sea. Mar Environ Res 43(4):265-278

Lien R, Solheim A, Elverhøi A, Rokoengen K (1989) Iceberg scouring and sea bed morphology on the eastern Weddell Sea shelf, Antarctica. Polar Res 7:43-57

Lorenzen S (1994) The phylogenetic systematics of freeliving nematodes. The Ray Society, Unwin Brothers Itd. The Gresham Press, Old Woking

Moens $T$, Vincx $M$ (1997) Observations on the feeding ecology of estuarine nematodes. J Mar Biol Assoc UK 77 : $211-227$

Montagna PA (1991) Meiobenthic communities of the Santa Maria Basin on the California continental shelf. Cont Shelf Res 11:1355-1378

Nothig EM (1988) On the ecology of the phytoplankton in the 
southeastern Weddell Sea (Antarctica) in January/February 1985. Ber Polarforsch 53:1-118

Pearson TH, Rosenberg R (1987) Feast and famine: structuring factors in marine benthic communities. In: Gee JHR, Giller PS (eds) The 27th Symposium of the British Ecological Society, Aberystwyth, 1986. Blackwell Scientific Publications, Oxiord, p 373-395

Pianka ER (1966) Latitudinal gradients in species diversity: a review of concepts. Am Nat 100(910):33-46

Pielou EC (1975) Ecological diversity. Wiley-Interscience, New York

Platt HM (1985) The freeliving marine nematode genus Sabatieria (Nematoda: Comesomatidae). Taxonomic revision and pictural keys. Zool J Linn Soc 83:27-78

Platt HM, Warwick RM (1988) Freeliving marine nematodes. Part 2. British chromadorids. Pictural key to world genera and notes for the identification of British species. Synopses of the British fauna, New Series 38. EJ Bill, Leiden

Rabitti S, Gouleau D, Boldrin A (1990) Suspended matter, phytoplankton and nutrients. In: Arntz W, Ernst W, Hempel I (eds) The expedition ANTARKTIS VII/4 (Epos leg 3) and VII/5 of RV 'Polarstern' in 1989. Ber Polarforsch 68:50-66

Renaud-Mornant JR, Gourbault N (1990) Evaluation of abyssal meiobenthos in the eastern central Pacific (ClarionClipperton fracture zone). Prog Oceanogr 24:317-329

Rohardt G, Ruhland G, Schleif U (1990) Physical oceanography. In: Arntz W, Ennst W, Hempel I (eds) The expedition ANTARKTIS VII/4 (Epos leg 3) and VII/5 of RV 'Polarstern' in 1989. Ber Polarforsch 68:39-49

Rutgers van der Loeff MM, Lavaleye MSS (1986) Sediments, fauna and the dispersal of radionuclides at the NE Atlantic dumpsite for low-level radioactive waste. Report of the DUTCH DORA program. Netherlands Institute of Sea Research, Texel

Seinhorst J (1959) A rapid method for the transfer of nematodes from fixative to anhydrous glycerin. Nematologica 4:67-69

Siegel S (1956) Non-parametric statistics for the behavioural sciences. McGraw-Hill \& Kogakusha Ltd, Tokyo

Soetaert K, Heip C (1995) Nematode assemblages of deep-sea and shelf break sites in the North Atlantic and Mediterranean Sea. Mar Ecol Prog Ser 125:171-183

Soetaert K, Vincx M (1988) Spirobolbolaimus bathyalis gen. nov. sp. nov. (Nematoda, Microlaimidae) from the Mediterranean (Calvi). Hydrobiologia 164:33-38

Soetaert K, Heip C, Vincx M (1991) Diversity of nematode assemblages along a Mediterranean deep-sea transect. Mar Ecol Prog Ser 75:275-282

Soetaert K, Vincx M, Heip C (1995) Nematode community structure along a Mediterranean shelf slope gradient. PSZN I: Mar Ecol 16:1-18

Strömberg JO (1996) Biodiversity and production in the ocean: frontiers and problems. In: Hempel $G$ (ed) The ocean and the poles: grand challenges for European cooperation. G Fischer, Jena, p 203-216

Ter Braak CJF (1988) CANOCO-a FORTRAN program for canonical community ordination by (partial) (detrended) (canonical) correspondence analysis, principal components analysis and redundancy analysis (Version 2.1). Agricultural Mat. Group, Ministry of Agriculture and Fisheries, Wageningen

Ter Braak CJF (1990) Update notes: CANOCO Version 3.10. Agricultural Mat. Group, Ministry of Agriculture and Fisheries, Wageningen

Thiel $H(1975)$ The size structure of the deep-sea benthos. Int Rev Gesamten Hydrobiol 60:575-606

Thiel $H$ (1983) Meiobenthos and nannobenthos in the deep- sea. In: Rowe GT (ed) The sea, Vol 8. J Wiley and Sons, New York, p 167-230

Thistle D (1978) Harpacticoid dispersion patterns: implications for deep-sea diversity maintenance. Deep-Sea Res 36:377-397

Thistle D, Sherman KM (1985) The nematode fauna of a deepsea site exposed to strong near-bottom currents. Deep-Sea Res 32(9): 1077-1088

Tietjen JH (1971) Ecology and distribution of deep-sea meiobenthos off North Carolina. Deep-Sea Res 18:941-957

Tietjen JH (1976) Distribution and species diversity of deep-sea nematodes off North Carolina. Deep-Sea Res 23:755-768

Tietjen JH (1984) Distribution and species diversity of deepsea nematodes in the Venezuela Basin. Deep-Sea Res 31: $119-132$

Tietjen JH (1989) Ecology of deep-sea nematodes from the Puerto Rico Trench area and Hatteras Abyssal Plain. Deep-Sea Res 36(10): 1579-1594

Todaro MA, Fleeger JW, Hu YP, Hrincevich AW, Foltz DW (1996) Are meiofaunal species cosmopolitan? Morphological and molecular analysis of Xenotrichula intermedia (Gastrotricha: Chaetonotida). Mar Biol 125:735-742

Tyler PA (1995) Conditions for the existence of life at the deep-sea floor: an update. Oceanogr Mar Biol Annu Rev 33:221-244

Tyson RV (1995) Sedimentary organic matter. Organic facies and palynofacies. Chapman \& Hall, London

Vanaverbeke J, Soetaert K, Heip C, Vanreusel A (1997a) The metazoan meiobenthos along the continental slope of the Goban Spur (NE Atlantic). J Sea Res 38:93-107

Vanaverbeke J, Arbizu PM, Dahms HU, Schminke HK (1997b) The metazoan meiobenthos along a depth gradient in the Arctic Laptev Sea with special attention to nematode communities. Polar Biol 18:391-401

Vanhove $S$, Wittoeck J, Desmet $G$, van den Berghe B, Herman RL, Bak RPM, Nieuwland G, Vosjan JH, Boldrin A, Rabitti $S$, Vincx M (1995) Deep-sea meiofauna communities in Antarctica: structural analysis and relation with the environment. Mar Ecol Prog Ser 127:65-76

Vanreusel A, Vincx M, van Gansbeke D, Gijselinck W (1992) Structural analysis of the meiobenthos communities of the shelf break area in two stations of the Gulf of Biscay (N.E. Atlantic). Belg J Zool 122(2):185-202

Vanreusel A, Vanden Bossche I, Thiermann F (1997) Free-living marine nematodes from hydrothermal sediments: similarities with communities from diverse reduced habitats. Mar Ecol Prog Ser 157:207-219

Vincx M, Meire P, Heip C (1990) The distribution of nematode communities in the Southern Bight of the North Sea. Cah Biol Mar 31:107-129

Vincx M, Bett BJ, Dinet A, Ferrero T, Gooday AJ, Lambshead PJD, Pfannkuche O, Soltwedel T, Vanreusel A (1994) Meiobenthos of the deep northeast Atlantic. Adv mar Biol 30: $1-88$

Vivier MH (1978a) Influence d'un déversement industriel profond sur la nématofaune (Canyon de Cassidaigne, Mediterranée). Tethys 8:307-321

Vivier MH (1978b) Conséquences d'un déversement de boue rouge d'alumine sur le méiobenthos profond (Canyon de Cassidaigne, Mediterranée). Tethys 8:249-262

Voß J (1988) Zoogeography and community analysis of macrozoobenthos of the Weddell Sea (Antarctica). Ber Polarforsch 45:1-145

Wetzel MA, Jensen P, Giere O (1995) Oxygen/sulfide regime and nematode fauna associated with Arenicola marina burrows: new insights in the thiobios case. Mar Biol 124: $301-312$ 
Whittaker RH (1960) Vegetation of the Siskiyou Mountains, Oregon and California. Ecol Monogr 30:279-338

Wieser W (1953) Beziehungen zwischen Mundhöhlengestalt,

Ernährungsweise und Vorkommen bei freilebenden marinen Nematoden. Ark Zool 2(4):439-484

Editorial responsibility: Otto Kinne (Editor),

Oldendort/Luhe, Germany
Wilson GDF, Hessler RR (1987) Speciation in the deep sea. Annu Rev Ecol Syst 18:185-207

Witte U, Brattegard T, Graf G, Springer B (1997) Particle capture and deposition by deep-sea sponges from the Norwegian-Greenland Sea. Mar Ecol Prog Ser 154:241-252

Submitted: March 2, 1998; Accepted: January 12, 1999 Proofs received from author(s): April 28, 1999 